\title{
Destinasyon Çekicilikleri Üzerine Bir Literatür Taraması: Türkiye, İspanya ve Yunanistan Karşılaştırması
}

\author{
A Literature Review on Destination Attributes: Comparison of Turkey, Spain and \\ Greece
}

Sezer KARASAKAL*

$\ddot{O} Z$

Destinasyon çekicilikleri, turistlerin destinasyon tercihlerinde ve memnuniyetleri üzerinde oldukça etkilidirler. Ele alınan bu çalışmanın amacl, Akdeniz'in önemli destinasyonları olan Türkiye, İspanya ve Yunanistan özelinde destinasyon çekiciliklerini ortaya koyan çalışmaları belirlemek ve bu çekicilikleri özellikleri bakımından gruplandırarak farklılıklar ve benzerliklerin ortaya konmasını sağlamaktır. Bu bakımdan bu çalışma bir literatür taraması niteliği taşımaktadır. Türkiye'den on, İspanya'dan altı ve Yunanistan'dan üç çalışma incelenmiştir. Çalışmaların incelenmesi neticesinde Türkiye 23, İspanya 22 ve Yunanistan ile ilgili 20 özellik oluşturulmuştur ve özelliklerin (doğa, tutum, hijyen ve temizlik) ülkeler arasında büyük oranda benzerlik gösterdiği görülmüş̧ür. Elde edilen bulgular ışığında, karar vericiler ve araştırmacılar için önerilerde bulunulmuştur.

ANAHTAR KELIMELER

Destinasyon çekicilikleri, Türkiye, İspanya, Yunanistan, Literatür taraması

\begin{abstract}
Destination attractiveness plays an important role on tourists' destination choice and satisfaction. This study aims to determine the researches focused on destination attractiveness of three important destinations of Mediterranean namely; Turkey, Spain and Greece. In doing so, this paper compares and contrasts the destination attractiveness of the aforementioned countries. In this regard, this study designed as a literature review. Ten studies were conducted in Turkey, six in Spain and three in Greece were analyzed. A synthesis of the studies revealed, 23 destination attributes for Turkey, 22 for Spain and 20 for Greece. Moreover, a vast majority of the attributes (nature, attitude, hygiene and cleanliness) in the countries under investigation were similar. Implications for theory and practice are discussed.
\end{abstract}

\section{KEYWORDS}

Destination attractiveness, Turkey, Spain, Greece, Literature review

\begin{tabular}{|c|c|c|}
\hline \multicolumn{2}{|r|}{$\begin{array}{c}\text { Makale Geliş Tarihi / Submission Date } \\
19.02 .2019\end{array}$} & $\begin{array}{c}\text { Makale Kabul Tarihi / Date of Acceptance } \\
\text { 12.03.2019 }\end{array}$ \\
\hline Atıf & $\begin{array}{l}\text { Karasakal, S. (2019). Destinasyon Ç } \\
\text { Karş1laştırması. Selçuk Üniversitesi So }\end{array}$ & $\begin{array}{l}\text { Literatür Taraması: Türkiye, İspanya ve Yunanistan } \\
\text { ksekokulu Dergisi, } 22 \text { (1),225-245. }\end{array}$ \\
\hline
\end{tabular}

\footnotetext{
* Araştırma Görevlisi, Antalya Bilim Üniversitesi Turizm Fakültesi, sezer.karasakal@ antalya.edu.tr, ORCID: 0000-0002-4713-2735
} 


\section{GİRIŞ}

Yeni destinasyonların ortaya çıkması, ülkeler ve şehirler arasındaki turist çekme rekabetinin giderek artmasına yol açtığı söylenebilir. Bu durum, özellikle birbirine coğrafi olarak yakın ve benzer turistik ürün sunan destinasyonlar için önemli bir durumdur. Birçok ülkede olduğu gibi, turizm Akdeniz'de bulunan ülkeler için de önemli bir sektördür (Falzon, 2012: 1080). Akdeniz ülkeleri birebir aynı olmasa da benzer turizm ürünleri sunmaktadırlar (Patsourais vd., 2005: 1866). Akdeniz havzasının önemli turizm ülkelerinden olan İspanya ve Yunanistan ile birlikte Türkiye, sahip olduğu doğal unsurları, tarihi, kültürel ve uygun fiyatları ile önemli destinasyonlardır (Yüksel, 2001: 153).

II. Dünya Savaşından sonra hızla artan paket tur anlayışı ile deniz, kum, güneş (3S) destinasyonları kitleler halinde turist çekmeye başlamıştır (Fayos-Sola, 1996: 405). Önemli bir 3S destinasyonu olan Türkiye, 2000'li yıllardan sonra büyüme trendine girmiş ve dünyanın en çok turist çeken destinasyonlarından biri olmuştur (Kozak, 2002: 511). Benzer şekilde, Yunanistan da sunduğu 3S temelli turistik ürünler ile ucuz bir tatil destinasyonu olarak görülmekte ancak tarihi ve kültürel unsurları ana çekicilikler olarak değerlendirilmemektedir. Diğer yandan, İspanya stratejisini 3S odaklı ürün tercih eden pazarlara yöneltmiş ve bunun yanında hizmet kalitesini de artırmayı amaçlamıştır (Patsouratis vd. 2005: 1866). Hizmet kalitesi gibi birçok unsur destinasyonun başarısı için oldukça önemlidir. Eşsiz bir doğa, sahiller, alışveriş imkanları, kültürel zenginlik, etkinlikler, altyapı gibi nitelikler ziyaretçilerin destinasyon seçimini etkiyen unsurlar (Mahdzar vd., 2015: 33) olmakla birlikte destinasyona rekabet avantajı sağlamaktadır (Haarhoff ve Gany, 2017: 2). Destinasyonda bulunan unsurlar daha fazla turist ve yüksek karlılık için önemlidir, fakat destinasyonun temel çekicilikleri genelde ziyaretçilerin bir destinasyonu alternatif olabilecek diğer destinasyonlara tercih etmesinin gerçek sebebi olabilir (Crouch, 2007'den aktaran Çelik, 2014: 23). Destinasyon karar vericileri de özgün ve ayırt edici çekicilikleri, turistlerin karar alma süreçlerinde dikkatlerini çekecek şekilde tanıtımını gerçekleştirmelidirler (Truong vd., 2018: 214). Çünkü, bazı kişiler için destinasyon özellikleri çekicilik olarak değil temel bir gereksinim olarak ifade edilmektedir (Albayrak ve Caber, 2013: 151).

$\mathrm{Bu}$ çalışmada, Akdeniz'in önemli destinasyonlarından ve birbirleri ile rekabet halinde olan Türkiye, İspanya ve Yunanistan'ın sahip olduğu destinasyon çekicilikleri karşılaştırılacaktır. Benzer ürün sunan destinasyonların karşılaştırılması, performanslarını ortaya koymak ve yeni pazar firsatlarını yakalamak adına önemli olacaktır (Goodall, 1990'dan aktaran Kozak, 2002: 503). Yapılan literatür çalışmasında, daha önce destinasyonların sahip olduğu çekiciliklerin karşılaştırıldığı bir çalışmaya rastlanmamıştır. Bu bağlamda, rekabet halinde olan bu üç destinasyonu konu alan çalışmalarda yer verilen çekicilik ile ilgili ifadelerin belirlenmesi ve ortaya konması önemli olduğu düşünülmektedir.

\section{KAVRAMSAL ÇERÇEVE}

\subsection{Destinasyon Kavramı ve Çekicilikleri}

Destinasyon, kişilerin tatil amaçlı ziyaret ettikleri ülke, bölge, şehir veya köylerdir. Dolayısıyla, destinasyon bir kıta (Afrika), birkaç ülkeden oluşan bölge (İskandinav ülkeleri), bir ülke (Türkiye), bir şehir (Antalya) olabileceği gibi, bir ada (Bozcaada), bir köy de (Sarıgerme) olabilir (Öter ve Özdoğan, 2005: 129; Çelik, 2014: 14). Bunlara ek olarak yolcu gemileri de (cruise) birer destinasyon olarak kabul edilebilmektedir (Buhalis, 2000: 97). Bu tanımlardan yola çıkarak destinasyonların içeriğinde birçok unsuru bulundurdukları söylenebilir. Bundan dolayı, literatürde birden fazla tanım yer almaktadır. Genel bir tanımlama yapan Gee vd. (1984) destinasyonu, turistlerin belirli bir süreliğine zaman geçirdikleri yerler olarak ifade etmişlerdir. Buhalis (2000: 97) destinasyonu, turizm ürünlerinin karmaşık olarak yer aldığı ve turistlere bütünleşik deneyim sunulan bir yer olarak tanımlamıştır. Geniş bir yelpazede ele alan Bahar ve Kozak (2012: 41) destinasyonu, bünyesinde çeşitli aktiviteleri bulunduran, doğal ve kültürel zenginliği olan, konaklama, ulaşım ve iletişim altyapısı olan, yiyecek-içecek hizmetlerinin sunulduğu, bununla birlikte kamusal hizmetlerinde verildiği imaj1 ve markası bulunan coğrafi bir bölge olarak tanımlamışlardır.

Alhroot (2007: 115- 117) çalışmasında destinasyon tanımını iki grup altında ele almıştır. Birincisi, klasik/geleneksel tanımı, ikincisi ise sosyolojik tanımıdır. Geleneksel tanım, destinasyonu coğrafi sınırı ve bünyesinde bulundurduğu çekicilikleri ortaya koyarken, sosyolojik tanım ise, ziyaretçilerin çekicilikler ve yerel halk ile etkileşimine odaklanmaktadır. Destinasyon çekicilikleri, ziyaretçileri çeken, çeşitli unsurların bir araya gelmesidir (Lew, 1987'den aktaran Kim, 2014: 34). MacCannell'a (1976: 109) göre, bir ürünün çekicilik olarak ifade edilebilmesi için üç unsur gereklidir: Turist, gezip görmek için uygun alan ve farklı kılacak bir imaj veya işaret. Dolayısıyla MacCannell bir ürünün turist ile buluşmaması durumunda çekicilik olarak ifade edilemeyeceğini ileri sürmüştür. Destinasyon çekicilikleri, literatürde farklı kavramlar ile eş anlamlı olarak 
kullanılmıştır. Örneğin, çekici faktörler (pull factors) (Klenosky, 2002: 385), destinasyon ürünü (product) (Mehmetoğlu ve Normann, 2013: 184; Xu, 2010: 607), destinasyon özellikleri (attributes) (Chahal ve Devi, 2015: 12) ve destinasyon kalitesi (destination quality) (Rajaratman vd., 2015: 465) gibi.

Destinasyonlar genellikle birbirinden farklı özelliklere sahip olmaktadır (Göker, 2018: 29). Prag tarihi unsurları, Mayorka 3S ile ön plana çıkabilmektedir. Bu farklılı̆̆ın sebebi, bazı destinasyonların doğal kaynak açısından çeşitli ve zengin olması veya tarih sahnesinde aldığı rol ile açıklanabilir (Aksöz, 2010: 7). Bu gibi zenginliğe sahip olmayan veya nispeten daha az sahip olan destinasyonlar ise insan yapımı çekiciliklerini ön plana çıkardığı söylenebilir. Örneğin, Florida'da bulunan Orlando şehri tema parkları (Walt Disney World, Universal Studios, Sea World) ile ön plana çıkmaktadır. Diğer yandan, bazı özellikleri bakımından benzer ürün sunan destinasyonlar da bulunmaktadir.

\section{METODOLOJI}

$\mathrm{Bu}$ çalı̧̧mada, Akdeniz çanağında bulunan ve turizm alanında birbirleri ile rekabet halinde olan Türkiye, İspanya ve Yunanistan destinasyonlarının çekicilikleri irdelenmiştir. Ele alınan bu çalışma kavramsal ve ampirik literatürün taranması niteliğindedir (Kuşluvan ve Eren, 2011: 141) ve literatür taramaları, daha önce ele alınmış çalışmalar hakkında detaylı bilgiler vermekle birlikte, daha sonra ele alınacak çalışmalar için potansiyel alanların belirlenmesi açısından oldukça önemlidir (Atrek ve Madran, 2017: 7). Türkiye, İspanya ve Yunanistan ile ilgili araştırmaları belirlemek amacıyla Türkçe ve İngilizce dillerinde ele alınmış kaynaklar taranmıştır. Çalışmalara ulaşmak amacıyla, SAGE, Taylor \& Francis, CABI, Emerald Insight, Google Scholar, Ulakbim, Ingenta, Wiley ve YÖK Ulusal Tez Merkezi veri tabanları taranmıştır. Kullanılan anahtar kelimler; destinasyon çekicilikleri (destination attractiveness), çekici faktörler (pull factors), destinasyon özellikleri (destination attributes) ve destinasyon ürünüdür (destination product). Farklı ülkeleri ele alan çalışmalar ise kapsam dişında tutulmuştur.

Tarama sonucunda, Türkiye ile ilgili on çalışmaya, İspanya ile ilgili altı çalışmaya ve Yunanistan ile ilgili üç çalışmaya ulaşılabilmiştir. Her bir ülke üzerine yapılan çalışmalar incelenerek destinasyon çekiciliklerini temsil eden ifadeler belirlenmiştir. Sonrasında, yazar tarafından, benzer özelliği temsil eden ifadeler aynı grup altında toplanarak (örn. yüksek kalite oteller, uygun konaklama ve konaklama tesisleri ifadeleri "konaklama" başlığ altında ele alınmıştır) benzerlik ve farklılık gösteren çekicilikler ortaya konmuştur. Türkiye ile ilgili yapılmış çalışmalarda 239 ifade gruplandırma kapsamında ele alınırken, İspanya ile ilgili 138 ifade ve Yunanistan için ise 67 ifade ele alınmıştır.

\section{BULGULAR}

\subsection{Türkiye'de Ele Alınmış Destinasyon Çekicilikleri Çalışmaları}

Türkiye'nin destinasyon çekicilikleri hakkında yapılmış on çalışmaya ulaşılmıştır. Bu çalışmalar; Muğgla (Fethiye, Bodrum, Marmaris) (Yüksel, 2001), Antalya (Aktaş vd., 2010; Özdemir vd., 2012; Caber vd., 2012; Albayrak ve Caber, 2013; Çetinsöz ve Artuğer, 2014), Antalya ve İstanbul'un beraber alındığı (Nikjoo ve Ketabi, 2015), Kuşadası (Güzel, 2017), Alanya (Pektaş, 2017) ve ülkenin bütün olarak ele alındığ1 çalışmalardan (Güzel ve Güzel, 2017) oluşmaktadır.

Yüksel (2001:162- 163) Muğla'y1 ilk kez ve birden fazla ziyaret eden turistlerin destinasyon çekiciliklerinden duydukları tatmini ve tekrar ziyaret niyetlerini incelemiştir. Farklı ülkelerden 343 ziyaretçiden oluşan çalışmada, 58 ifade ile destinasyon çekicilikleri ele alınmıştır. Faktör analizi sonucunda 16 boyut (yiyecek-içecek kalitesi, hizmet kalitesi, konaklama, misafirperverlik, turistik tesis hizmetleri, sahil ve çevre, fiyat ve değer, eğlence, sessizlik, uygunluk, iletişim, güvenlik, su sporları, ulaşım, havaalanı hizmetleri, hava) belirlenmiştir.

Aktaş vd. (2010: 246) destinasyon çekicilikleri ile tatilden memnun olma ve davranışsal niyet arasındaki ilişkiyi incelemişlerdir. Alanya'da farklı milletlerden 2125 ziyaretçi ile yapılan çalışmada, destinasyon çekicilikleri 23 ifadede (1= tamamen katılmıyorum, 5= tamamen katılıyorum) ele alınmıştır. Faktör analizi sonucunda ifadeler üç boyut (destinasyon olanakları, konaklama hizmetleri, karşılayıcı seyahat acentesinin hizmetleri) altında toplanmıştır

Destinasyon çekiciliklerinin tatmin olma üzerine asimetrik ve simetrik etkisini ortaya koymak amaciyla Antalya destinasyonunda Albayrak ve Caber' in (2012: 150) farklı ülkelerden 1576 ziyaretçi ile gerçekleştirdikleri çalışmada 21 ifade (1= tamamen katılmıyorum, 5= tamamen katılıyorum) ile çekicilikler ele alınmıştır. Analiz neticesinde beş boyut (sağlık ve hijyen, alışveriş, bilgi, yerel ulaşım, konaklama) elde edilmiştir. 
Özdemir vd. (2012: 534) Antalya'nın sahip olduğu destinasyon çekiciliklerinden duyulan memnuniyet düzeylerini ölçmek amacıyla, farklı ülkelerden gelen 10393 ziyaretçiden veri elde etmişlerdir. Çalışmada 18 ifadeye ( $1=$ Kesinlikle tatmin olmadım, $7=$ kesinlikle tatmin oldum) yer verilmiştir.

Caber vd. (2012: 44-48) önem-performans analizi ile Antalya destinasyonun sahip olduğu çekiciliklerin ziyaretçiler gözünde nasıl göründüğünü ortaya çıkarmayı amaçlamışlardır. Bu bağlamda, 20 ifade ile ölçülen destinasyon çekicilikleri Alman, Hollandalı, İngiliz ve Rus ziyaretçiler $(n=821)$ tarafından değerlendirilmiştir. Katılımcıların milliyetlerine göre, memnuniyetleri, tavsiye etmeleri ve tekrar satın alma niyetleri üzerinde anlamlı farklılar olduğu ortaya konmuştur. Diğer yandan, dört ülke vatandaşlarının destinasyon seçiminde en önemli gördükleri kriterlerin misafirperverlik, iklim ve güvenlik olduğu ortaya konmuştur.

Çetinsöz ve Artuğer (2014: 575) Antalya'yı ziyaret eden, çoğunluğu Alman ve Rus olan farklı milletten 408 kişi ile yaptıkları çalışmada, destinasyon çekiciliklerini 19 ifade $(1=$ hiç etkili değildir, 5= tamamen etkilidir) ile ölçmüşlerdir. Ortaya çıkan boyutlar ise; sosyal aktiviteler, tarihi ve kültürel değerler, hijyen ve güvenlik, doğal güzellikler, fiyat olmuştur.

İranlı ziyaretçilerin seyahat motivasyonlarını inceleyen Nikjoo ve Ketabi (2015: 588), rekreatif ürün sunan (Antalya) ve ağırlıklı olarak kültürel (İstanbul) çekicilikleri ile ön planda olan iki farklı destinasyonu ele almışlardır. İranlı 401 kişi ile yapılan çalışmada 17 çekicilik ifadesi, analiz neticesinde beş boyut altında (erişim, altyap1, eğlence, çekicilikler, alışveriş) gruplanmıştır.

Güzel ve Güzel (2017: 209) iki grubun (filmlerden esinlenerek Türkiye'ye gelen ziyaretçiler ve diğer ziyaretçiler) çekicilikler üzerindeki algı farklarını ortaya koymak ve çekiciliklerin tatmin olma üzerindeki etkisini ortaya koymak amacıyla 270 Arap turist üzerinde bir araştırma gerçekleştirmişlerdir. Çalışmada yer alan 23 ifade yedi boyut (helallik, yerellik, alışveriş olanakları, kültür ve iklim, aktiviteler, fiziksel çevre, doğal güzellik) oluşturmuş̧tur.

Güzel (2017: 128-132) destinasyon çekiciliklerini turistler açısından değil, yerel halkın bakış açısından ele almıştır. Kuşadası'nda yaşayan 295 kişi ile yapılan çalışmada, destinasyon çekicilikleri 27 ifade değerlendirmeye alınmış ve yerel halk için önemli olup olmadıkları ortaya konmaya amaçlanmıştır. Faktör analizi sonucunda dört boyut (tesisler ve atmosfer, yerellik, tarihi, dini ve doğal yerler ve imaj) ortaya konmuştur.

Pektaş (2017: 41) çalışmasında seyahat motivasyonu oluşturan itici ve çekici faktörler ile tüketici temelli destinasyon değeri arasındaki ilişkiyi ortaya koymayı ve seyahat motivasyonun tüketici temelli destinasyon değeri üzerindeki etkisini belirlemeyi amaçlamıştır. Alanya'yı ziyaret eden 468 ziyaretçiden veri toplanmıştır. Çalışmada Alanya'nın çekici faktörlerini ölçmek amacıyla 24 ifade kullanılmıştır ve bu ifadeler iki boyut altında toplanmıştır (geniş kapsamlı çekici faktörler ve dar kapsamlı çekici faktörler).

Tablo 1'de, Türkiye' de bulunan destinasyonların çekiciliklerine yer veren on çalışmada yer alan ifadelerin sınıflandırılmış şekilde ortaya konmaya çalışılmıştır. Ele alınan 239 ifade, 23 özellik altında ele alınmıştır. Yazar, kendi içerisinde benzer olan ifadeleri bir araya getirerek ortak bir özellik altında toplamıştır. Bunlar; eğlence, altyapı, güvenlik, alışveriş, konaklama, tarihi ve kültürel unsurlar, tutum, hizmet, fiyat, hijyen ve temizlik, yiyecek-içecek, doğa, aktivite, erişim, destekleyici, bilgi vericilik, iletişim, olumsuz unsurlar, çekicilikler, huzur, havaalanı, aile odaklılık ve diğerdir.

\section{2.İspanya'da Ele Alınmış Destinasyon Çekicilikleri Çalışmaları}

İspanya ile ilgili altı çalışma incelenmiştir. Bunlardan üç tanesi Balear Adalarını (Alegre ve Cladera, 2006; Campo ve Garau, 2008; Alegre ve Cladera, 2009), iki çalışma yine Balear adalarından bir tanesi olan Mayorka'y1 (Kozak ve Rimmington, 2000; Marin ve Taberner, 2008) ve Calpe (Kozak vd., 2004) destinasyonlarını ele almışlardır. Balear Adası, İspanya'nın önemli deniz-kum-güneş destinasyonu olması sebebiyle ve kitleler halinde ziyaretçi çekmesi sebebiyle araştırmacıların dikkatini çekmiştir. Kozak ve Rimmington (2000: 260-265) 220 Britanyalı turistin destinasyondan tatmin olma durumlarını incelemişlerdir. Destinasyon çekicilikleri 30 ifade ile ele alınmıştır. İfadeler faktör analizi sonucunda dört boyut (destinasyon çekicilikleri, turist çekicilikleri ve tesisler, İngilizcenin kullanımı, destinasyon havaalanında bulunan tesisler ve hizmetler) altında toplanmıştır.

İlk defa gelenler ve tekrar gelenlerin destinasyon çekiciliklerinden duydukları tatmin duygusunu ve sadakat durumlarını ortaya koymayı amaçlayan Kozak vd. (2004: 46) İspanya'nın Akdeniz kıyısında bulunan ve temelde deniz-kum-güneş odaklı turizm ürünü sunan Calpe destinasyonu dikkate ele almışlardır. Çalışma farklı ülkelerden 806 ziyaretçi üzerinde gerçekleşmiştir ve 22 destinasyon çekicilikleri ifadesine (1= çok iyi, $5=$ çok kötü) yer verilmiştir.

Alegre ve Cladera 2006 ve 2009 yıllarında yaptıkları araştırmada Balear Adası Bölgesi Yönetimi'nin (Balearic Island Regional Government) 1986 yılından itibaren yıllık olarak gerçekleştirdiği Turist Harcama 
Anketi'nin verilerinden faydalanmışlardır. Çalışmalarda örneklem grubu farklı ülke vatandaşlarından oluşmuştur ve destinasyon çekicilikleri 20 ifade $(1=$ hiç tatmin olmadım, $10=$ çok tatmin oldum $)$ ile ölçülmüştür (Alegre ve Cladera, 2006: 294; Alegre ve Cladera, 2009: 676).

Marin ve Taberner (2008: 12-14) Mayorka destinasyonunda yaptıkları çalışmada hem pozitif destinasyon çekiciliklerinin hem de negatif destinasyon çekiciliklerinin genel tatmine ve tekrar ziyarete etkisini incelemişlerdir. Çalışma, örneklem grubunu Alman, İngiliz ve İspanyolların oluşturduğu 2423 ziyaretçi oluşturmaktadır. Pozitif çekicilikler altı boyut (güneş ve kum destinasyonu ürünü, destinasyon özellikleri, aktivite ve sosyal etkileşim, kolaylık, mutfak ve yerel yaşam biçimi, fiyat) negatif özellikler ise iki boyut altında toplanmıştır. 
Tablo 1. Türkiye ile İlgili Destinasyon Çekiciliklerinin Sınıflandırılması

\begin{tabular}{|c|c|c|c|c|c|}
\hline \multicolumn{2}{|c|}{ Güvenlik } & \multicolumn{2}{|c|}{ Altyapı } & \multicolumn{2}{|c|}{ Alışveriş } \\
\hline $\begin{array}{l}\cdot \text { Kişisel güvenlik } \\
\cdot \text { Güvenli ülke } \\
\cdot \text { Güvenli bir şehir } \\
\cdot \text { Kişisel güvenlik } \\
\cdot \text { Güvenlik } \\
\cdot \text { Bölgenin güvenliği } \\
\text { · Otelin güvenliği } \\
\text { · Bölgede güvende hissetme } \\
\text { · Otelde güvenlik } \\
\text { - Odalarda güvenlik } \\
\text { - Güvenlik }\end{array}$ & $\begin{array}{l}\text { Pektaş, } \\
\text { 2017; Güzel } \\
\text { ve Güzel, } \\
\text { 2017; } \\
\text { Çetinsöz ve } \\
\text { Artuğer, } \\
\text { 2014; } \\
\text { Özdemir vd., } \\
\text { 2012; Caber } \\
\text { vd., 2012; } \\
\text { Aktaş vd., } \\
\text { 2010; } \\
\text { Yüksel, } \\
2001 ; \text { Güzel, } \\
2017\end{array}$ & $\begin{array}{l}\cdot \text { Altyapı kalitesi } \\
\cdot \text { Elverişli ulaşım } \\
\cdot \text { Ulaşım } \\
\cdot \text { Ulaşım kolaylığı } \\
\cdot \text { Uygun ulaşım } \\
\cdot \text { Yerel araçların konforu } \\
\cdot \text { Ulaşım hizmetlerinin sıklığ1 } \\
\cdot \text { Genel olarak ulaşım sistemi } \\
\cdot \text { Yerel ulaşım hizmetleri } \\
\cdot \text { Ulaşım tesisleri (bölgede) } \\
\cdot \text { Gelişmiş altyapı } \\
\cdot \text { Elektrik ve su arzının } \\
\text { yeterliliği } \\
\text { Toplu taşımanın etkinliği }\end{array}$ & $\begin{array}{l}\text { Pektaş, 2017; } \\
\text { Güzel ve } \\
\text { Güzel, 2017; } \\
\text { Güzel, 2017; } \\
\text { Nikjoo ve } \\
\text { Ketabi, 2015; } \\
\text { Albayrak ve } \\
\text { Caber, 2013; } \\
\text { Özdemir vd., } \\
\text { 2012; Caber } \\
\text { vd., 2012; } \\
\text { Yüksel, 2001 }\end{array}$ & $\begin{array}{l}\text { ·Alışveriş olanakları } \\
\text { · Alışveriş merkezleri } \\
\text { · Markalı alışveriş } \\
\text { mağazaları } \\
\text { · Zengin alışveriş } \\
\text { olanakları } \\
\text { · Yerel Pazar } \\
\text { · Alışveriş merkezleri } \\
\text { - Alışveriş imkanları } \\
\text { - Alışveriş } \\
\text { · Yeterli alışveriş } \\
\text { firsatları } \\
\text { · Ürünler üzerindeki } \\
\text { fiyat etiketleri }\end{array}$ & $\begin{array}{l}\text { Pektaş, 2017; } \\
\text { Güzel ve } \\
\text { Güzel, 2017; } \\
\text { Güzel, 2017; } \\
\text { Nikjoo ve } \\
\text { Ketabi, 2015; } \\
\text { Özdemir vd., } \\
\text { 2012; Caber } \\
\text { vd., 2012; } \\
\text { Aktaş vd., } \\
\text { 2010 }\end{array}$ \\
\hline \multicolumn{2}{|c|}{ Destekleyici unsurlar } & \multicolumn{2}{|c|}{ Erişim } & \multicolumn{2}{|c|}{ Diğer } \\
\hline $\begin{array}{l}\text { - Dinsel alanlar } \\
\text {-Sahilde tesislerin } \\
\text { mevcudiyeti } \\
\text {-Sağlık ve wellness } \\
\text { olanakları } \\
\text {-Döviz bozdurma olanakları }\end{array}$ & $\begin{array}{l}\text { Güzel, 2017; } \\
\text { Yüksel, } \\
\text { 2001; Caber } \\
\text { vd., 2012; } \\
\text { Albayrak ve } \\
\text { Caber, 2013; } \\
\text { Nikjoo ve } \\
\text { Ketabi, 2015 }\end{array}$ & $\begin{array}{l}\cdot \text { Ulaşılabilirlik } \\
\cdot \text { Erişim (bölgeye) } \\
\cdot \text { Kolay ulaşım } \\
\cdot \text { İ́ranlılar için kolay erişim }\end{array}$ & $\begin{array}{l}\text { Özdemir vd., } \\
\text { 2012; Caber } \\
\text { vd., 2012; } \\
\text { Aktaş vd., } \\
\text { 2010; Nikjoo } \\
\text { ve Ketabi, } \\
2015\end{array}$ & $\begin{array}{l}\cdot \text { Köyler } \\
\cdot \text { Şehrin imajı } \\
\cdot \text { İ́ranlılara vize } \\
\text { muafiyeti } \\
\cdot \text { Tatil planı yapmanın } \\
\text { kolaylığı } \\
\cdot \text { Uygun özgürlük } \\
\cdot \text { Rezervasyonlar }\end{array}$ & $\begin{array}{l}\text { Güzel, 2017; } \\
\text { Nikjoo ve } \\
\text { Ketabi, 2015; } \\
\text { Aktaş vd., } \\
2010\end{array}$ \\
\hline
\end{tabular}




\begin{tabular}{|c|c|c|c|c|c|}
\hline \multicolumn{2}{|c|}{ Yiyecek-içecek } & \multicolumn{2}{|l|}{ Tutum } & \multicolumn{2}{|c|}{ Tarihi ve kültürel unsurlar } \\
\hline 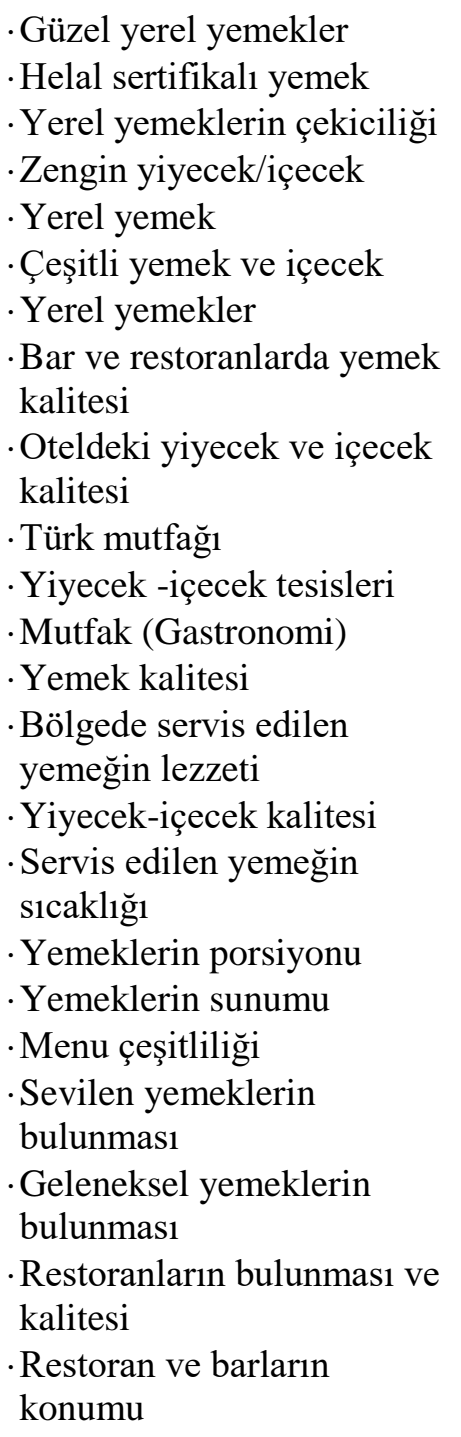 & $\begin{array}{l}\text { Pektaş, 2017; } \\
\text { Güzel ve } \\
\text { Güzel, 2017; } \\
\text { Güzel, 2017; } \\
\text { Nikjoo ve } \\
\text { Ketabi, 2015; } \\
\text { Çetinsöz ve } \\
\text { Artuğer, } \\
\text { 2014; } \\
\text { Albayrak ve } \\
\text { Caber, 2013; } \\
\text { Özdemir vd., } \\
\text { 2012; Caber } \\
\text { vd., 2012; } \\
\text { Aktaş vd., } \\
\text { 2010; } \\
\text { Yüksel, 2001 }\end{array}$ & $\begin{array}{l}\cdot \text { İlginç ve arkadaş canlısı yerel } \\
\text { halk } \\
\cdot \text { İnsanların } \\
\text { Sıcakkanlılığı/misafirperverliği } \\
\cdot \text { Sıcakkanlı yerel halk } \\
\cdot \text { Mağaza çalışanlarının } \\
\text { müşterilere yaklaşımı } \\
\cdot \text { Mağaza çalışanlarının } \\
\text { turistlere tutumu } \\
\cdot \text { Mağazacıların dürüstlüğü } \\
\cdot \text { Yerel sürücülerin davranışları } \\
\cdot \text { Otel personelinin tutumu } \\
\cdot \text { Yerel halkın misafirperverliği } \\
\cdot \text { Misafirperverlik } \\
\cdot \text { Halkın misafirperverliği } \\
\cdot \text { Misafirperver personel } \\
\cdot \text { Personelin tutumu } \\
\cdot \text { Konaklama işletmesinde güler } \\
\text { yüzlü hizmet } \\
\cdot \text { Yerel halkın nezaketi } \\
\cdot \text { Çalışanların nezaketi } \\
\text {-Çalışanların yardım etme } \\
\text { istekliliği } \\
\cdot \text { Yerel halkın yardım etme } \\
\text { istekliliği } \\
\cdot \text { İnsanların sıcakkanlılığı } \\
\cdot \text { Turistik tesislerde hizmetin } \\
\text { nezaketi }\end{array}$ & $\begin{array}{l}\text { Pektaş, 2017; } \\
\text { Güzel ve } \\
\text { Güzel, 2017; } \\
\text { Albayrak ve } \\
\text { Caber, 2013; } \\
\text { Özdemir vd., } \\
\text { 2012; Caber } \\
\text { vd., 2012; } \\
\text { Aktaş vd., } \\
\text { 2010; Yüksel, } \\
\text { 2001 }\end{array}$ & 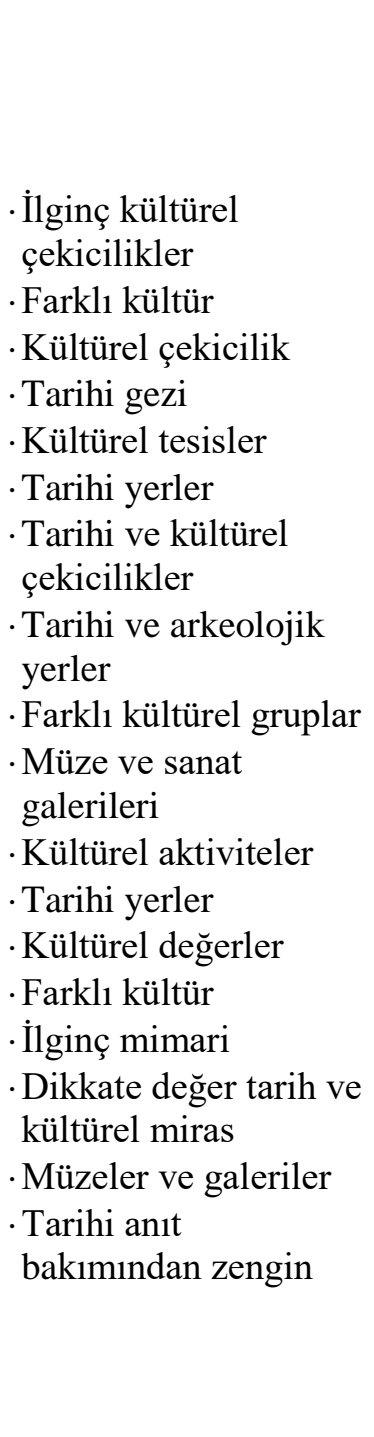 & $\begin{array}{l}\text { Pektaş, } \\
\text { 2017; Güzel } \\
\text { ve Güzel, } \\
\text { 2017; Güzel, } \\
\text { 2017; Nikjoo } \\
\text { ve Ketabi, } \\
\text { 2015; } \\
\text { Çetinsöz ve } \\
\text { Artuğer, } \\
\text { 2014; } \\
\text { Özdemir vd., } \\
\text { 2012; Caber } \\
\text { vd., 2012; } \\
\text { Aktaş vd., } \\
\text { 2010 }\end{array}$ \\
\hline
\end{tabular}




\begin{tabular}{|c|c|c|c|c|c|}
\hline \multicolumn{2}{|c|}{ Konaklama } & \multicolumn{2}{|c|}{ Doğa } & \multicolumn{2}{|c|}{ Hizmet } \\
\hline $\begin{array}{l}\cdot \text { Uygun konaklama } \\
\text { olanakları } \\
\cdot \text { Helal sertifikalı otel } \\
\cdot \text { İyi-kalite konaklama } \\
\cdot \text { Yüksek kalite oteller } \\
\cdot \text { Uygun konaklama } \\
\cdot \text { Konaklama tesisleri } \\
\cdot \text {-Yüksek kalite konaklama } \\
\cdot \text { Konforlu otel } \\
\cdot \text { Konaklamada } \\
\text { işletmesinde check in ve } \\
\text { check out işlemlerinin } \\
\text { etkinliği } \\
\cdot \text { Konaklama işletmesinde } \\
\text { etkin hizmet } \\
\cdot \text { Konaklama işletmesinin } \\
\text { fiziksel durumu } \\
\cdot \text { Konaklama işletmesinde } \\
\text { sunulan olanakların } \\
\text { kalitesi } \\
\cdot \text { Odaların konforu } \\
\cdot \text { Konaklama işletmesinin } \\
\text { konumu } \\
\cdot \text { Konaklama işletmesinde } \\
\text { ses düzeyi } \\
\cdot \text { Her şey dahil tatil } \\
\text { olanakları } \\
\cdot \text { Konaklama işletmesinde } \\
\text { bulunan restoran ve } \\
\text { barların ses düzeyi }\end{array}$ & $\begin{array}{l}\text { Pektaş, 2017; } \\
\text { Güzel ve } \\
\text { Güzel, 2017; } \\
\text { Güzel, 2017; } \\
\text { Nikjoo ve } \\
\text { Ketabi, 2015; } \\
\text { Özdemir vd., } \\
\text { 2012; Caber } \\
\text { vd., 2012; } \\
\text { Aktaş vd., } \\
\text { 2010; } \\
\text { Yüksel, } 2001\end{array}$ & 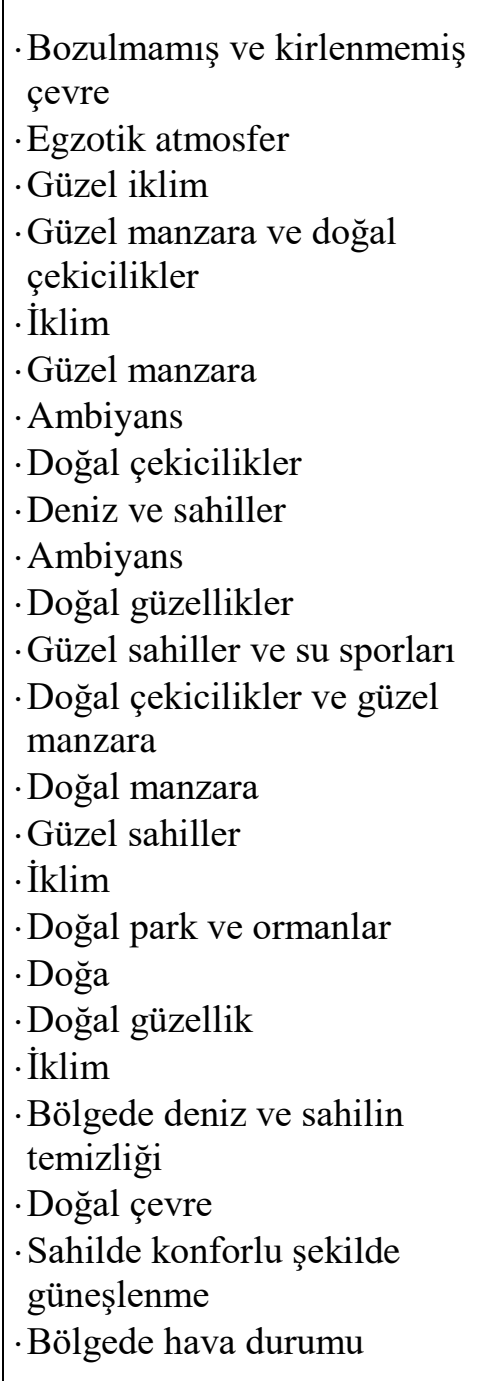 & $\begin{array}{l}\text { Pektaş, 2017; } \\
\text { Güzel ve } \\
\text { Güzel, 2017; } \\
\text { Güzel, 2017; } \\
\text { Nikjoo ve } \\
\text { Ketabi, 2015; } \\
\text { Çetinsöz ve } \\
\text { Artuğer, } \\
\text { 2014; } \\
\text { Özdemir vd., } \\
\text { 2012; Caber } \\
\text { vd., 2012; } \\
\text { Yüksel, 2001 }\end{array}$ & $\begin{array}{l}\text {-Şikâyet etmek veya } \\
\text { bilgi alacak } \\
\text { otoritelerin bulunması } \\
\text { ·Hizmet kalitesi } \\
\text {-Acentenin uzmanlığı } \\
\text {-Rehber hizmetleri } \\
\text {-Personelin yetkinliği } \\
\text {-Personelin taleplere } \\
\text { cevap verebilirliği } \\
\text {-Personelin şikayetlere } \\
\text { cevap verebilirliği } \\
\text {-Turistik tesislerde } \\
\text { hizmetin etkinliği } \\
\text {-Turistik tesislerde } \\
\text { hizmet için bekleme } \\
\text { süresi } \\
\text {-Turistik tesislerde } \\
\text { hizmet kalitesi } \\
\text {-Turistik tesislerde } \\
\text { çalışma saatlerinin } \\
\text { uygunluğu } \\
\text {-Turların ve cruise } \\
\text { bulunması }\end{array}$ & $\begin{array}{l}\text { Albayrak ve } \\
\text { Caber, 2013; } \\
\text { Aktaş vd., } \\
\text { 2010; } \\
\text { Yüksel, } 2001\end{array}$ \\
\hline
\end{tabular}




\begin{tabular}{|c|c|c|c|c|c|}
\hline \multicolumn{2}{|c|}{ Çekicilikler } & \multicolumn{2}{|c|}{ Olumsuz unsurlar } & \multicolumn{2}{|c|}{ Huzur } \\
\hline · Modern çekicilikler & $\begin{array}{l}\text { Nikjoo ve } \\
\text { Ketabi, } 2015\end{array}$ & - Bölgede kalabalıklık düzeyi & Yüksel, 2001 & $\begin{array}{l}\cdot \text { Huzurlu ve sessiz } \\
\text { şehir }\end{array}$ & Güzel, 2017 \\
\hline \multicolumn{2}{|c|}{ Fiyat } & \multicolumn{2}{|c|}{ Hijyen ve temizlik } & \multicolumn{2}{|c|}{ Eğlence } \\
\hline 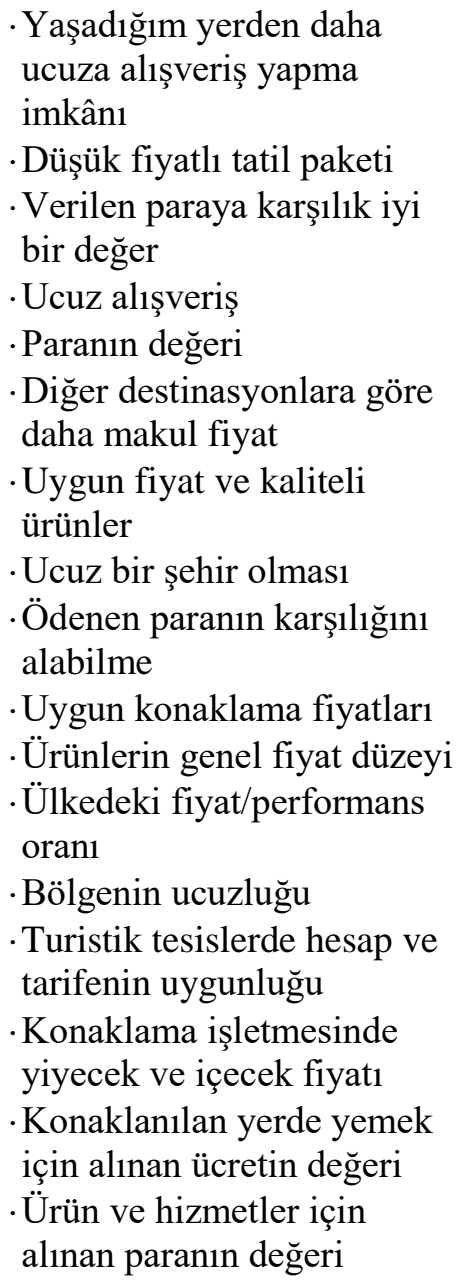 & $\begin{array}{l}\text { Pektaş, 2017; } \\
\text { Güzel ve } \\
\text { Güzel, 2017; } \\
\text { Güzel, 2017; } \\
\text { Nikjoo ve } \\
\text { Ketabi, 2015; } \\
\text { Çetinsöz ve } \\
\text { Artuğer, } \\
\text { 2014; } \\
\text { Albayrak ve } \\
\text { Caber, 2013; } \\
\text { Caber vd., } \\
\text { 2012; Aktaş } \\
\text { vd., 2010; } \\
\text { Yüksel, 2001 }\end{array}$ & $\begin{array}{l}\cdot \text { Standart hijyen ve temizlik } \\
\cdot \text { Temiz hijyenik otel } \\
\cdot \text { Temizlik } \\
\cdot \text { Tatmin edici sanitasyon } \\
\cdot \text { Standart hijyen ve temizlik } \\
\text { koşulları } \\
\cdot \text { Havasının ve suyunun } \\
\text { temizliği } \\
\cdot \text { Genel çevre temizliği } \\
\cdot \text { Yiyecek ve içeceğin temizliği } \\
\cdot \text { Kamu tuvaletlerinin temizliği } \\
\cdot \text { Otelin genel temizliği } \\
\cdot \text { Temizlik } \\
\cdot \text { Hijyen } \\
\cdot \text { Bölgenin temizliği } \\
\cdot \text { Sahillerin temizliği } \\
\cdot \text { Otelin temizliği } \\
\cdot \text { Yemeklerin hijyenik } \\
\text { hazırlanması } \\
\cdot \text { Konaklama işletmesinin } \\
\text { temizliği } \\
\cdot \text { Konaklama işletmesinde } \\
\text { bulunan restoranın temizliği } \\
\cdot \text { Odaların temizliği } \\
\cdot \text { Ürün ve hizmetler için alınan } \\
\text { paranın değeri }\end{array}$ & $\begin{array}{l}\text { Güzel ve } \\
\text { Güzel, 2017; } \\
\text { Güzel, 2017; } \\
\text { Nikjoo ve } \\
\text { Ketabi, 2015; } \\
\text { Çetinsöz ve } \\
\text { Artuğer, } \\
\text { 2014; } \\
\text { Albayrak ve } \\
\text { Caber, 2013; } \\
\text { Özdemir vd., } \\
\text { 2012; Aktaş } \\
\text { vd., 2010; } \\
\text { Yüksel, 2001 }\end{array}$ & $\begin{array}{l}\cdot \text { Eğlence ve tema } \\
\text { parkları } \\
\cdot \text { Güzel gece hayatı ve } \\
\text { eğlence } \\
\cdot \text {-Eğlence yerleri } \\
\cdot \text { Rekreasyon yerleri } \\
\cdot \text {-Gece hayatı } \\
\cdot \text { Eğlence } \\
\cdot \text { Eğlenceli gece hayatı } \\
\cdot \text { Eğlence Parkları } \\
\cdot \text { Gece Hayatı ve } \\
\text { eğlence } \\
\cdot \text { Gece hayatı } \\
\cdot \text { Canlı gece hayatı } \\
\cdot \text { Yeterli rekreatif } \\
\text { tesisler } \\
\cdot \text { Animasyon ve spor } \\
\text { tesisleri } \\
\cdot \text { Eğlencenin olması ve } \\
\text { kalitesi }\end{array}$ & $\begin{array}{l}\text { Pektaş, 2017; } \\
\text { Güzel ve } \\
\text { Güzel, 2017; } \\
\text { Güzel, 2017; } \\
\text { Nikjoo ve } \\
\text { Ketabi, 2015; } \\
\text { Çetinsöz ve } \\
\text { Artuğer, } \\
\text { 2014; Caber } \\
\text { vd., 2012; } \\
\text { Aktaş vd., } \\
\text { 2010; } \\
\text { Yüksel, } 2001\end{array}$ \\
\hline
\end{tabular}




\begin{tabular}{|c|c|c|c|c|c|}
\hline \multicolumn{2}{|c|}{ Aktivite } & \multicolumn{2}{|c|}{ Bilgi vericilik } & \multicolumn{2}{|c|}{ Havaalanı } \\
\hline $\begin{array}{l}\text {-Açıkhava aktiviteleri } \\
\text {-Su sporları } \\
\text {-Spor faaliyetleri } \\
\text {-Su sporları } \\
\text {-Su sporları } \\
\text {-Sportif Faaliyetler } \\
\text {-Spor aktiviteleri } \\
\text { - Illginç organizasyonlar ve } \\
\text { aktiviteler } \\
\text {-Su sporlarının bulunması }\end{array}$ & $\begin{array}{l}\text { Pektaş, 2017; } \\
\text { Güzel ve } \\
\text { Güzel, 2017; } \\
\text { Güzel, 2017; } \\
\text { Çetinsöz ve } \\
\text { Artuğer, } \\
\text { 2014; } \\
\text { Özdemir vd., } \\
\text { 2012; Caber } \\
\text { vd., 2012; } \\
\text { Yüksel, 2001 }\end{array}$ & $\begin{array}{l}\text {-Turizm bilgi büro hizmetleri } \\
\text {-Bölge hakkında harita ve } \\
\text { broşür elde etme olanakları } \\
\text {-Bilgi verici işaret ve semboller } \\
\text { - Turist bilgilendirme } \\
\text { - Bilgi verme hizmetleri }\end{array}$ & $\begin{array}{l}\text { Albayrak ve } \\
\text { Caber, 2013; } \\
\text { Özdemir vd., } \\
\text { 2012; Aktaş } \\
\text { vd., } 2010\end{array}$ & $\begin{array}{l}\cdot \text { Havaalanı transferi } \\
\cdot \text { Havaalanında check } \\
\text { in ve check out } \\
\text { işleminin etkinliği }\end{array}$ & $\begin{array}{l}\text { Aktaş vd., } \\
2010 ; \\
\text { Yüksel, } 2001\end{array}$ \\
\hline \multicolumn{2}{|c|}{ Aile odaklılık } & \multicolumn{2}{|c|}{ İletişim } & & \\
\hline $\begin{array}{l}\text { - Aile odaklı } \\
\text { - Aile tatili için uygunluk } \\
\text { - Çocuk kabulü }\end{array}$ & $\begin{array}{l}\text { Pektaş, 2017; } \\
\text { Özdemir vd., } \\
\text { 2012; Caber } \\
\text { vd., } 2012\end{array}$ & $\begin{array}{l}\text { - Yerel halk ile kendi dilinde } \\
\text { iletişim kurma kolaylığ } 1 \\
\text { · Personelle kendi dilinde } \\
\text { iletişim kurma } \\
\text { - Dil engelinin olmaması } \\
\text { · Yerel halk ile etkileşim }\end{array}$ & $\begin{array}{l}\text { Yüksel, 2001; } \\
\text { Caber vd., } \\
\text { 2012; } \\
\text { Özdemir vd., } \\
2012\end{array}$ & & \\
\hline
\end{tabular}


Mayorka'y1 ele alan diğer bir çalışma Campo ve Garau (2008: 85-86) tarafindan ele alınmıştır. Mayorka adasının çekiciliklerini yansıtan 11 ifade ( $1=$ tamamen tatmin olmadım, 10= tamamen tatmin oldum) dört boyut (destinasyonun özelliklerine karşı tatmin olma, çevresel tatmin olma, fiyatlardan tatmin olma, misafirperverlikten tatmin olma) altında toplanmıştır. Çalışma farklı ülkelerden 529 katılımcı ile gerçekleştirilmiştir.

Tablo 2'de İspanya' da bulunan destinasyonları ele alınmış altı çalışmaya yer verilmiştir. Çalışmalarda destinasyon çekicilikleri ile ilgili kullanılan toplam 138 ifade sınıflandırma sonucunda 22 özellik altında toplanmıştır. Bunlar; eğlence, altyapı, güvenlik, alışveriş, konaklama, tarihi ve kültürel unsurlar, tutum, hizmet, fiyat, hijyen ve temizlik, yiyecek-içecek, doğa, aktivite, bilgi vericilik, iletişim, destekleyici unsurlar ve diğerdir.

\subsection{Yunanistan'da Ele Alınmış Destinasyon Çekicilikleri Çalışmaları}

Yunanistan ile ilgili yapılmış destinasyon çekiciliklerine yer veren üç çalışma (Andriotis vd., 2018; Vassiliadis, 2008; Assiouras vd., 2015) incelenmiş̧tir. Andriotis vd. (2008: 221) Yunanistan'ın Girit adasını ziyaret eden turistlerin tatmin olma durumlarını incelemek ve bölümlendirme yapmak amacıyla çalışma yürütmüşlerdir. Farklı ülkelerden 870 ziyaretçi ile yapılan çalışmada destinasyon çekiciliklerinden duyulan tatmin olma durumunu ölçmek için 25 ifade $(1=$ kesinlikle tatmin olmadım, $7=$ kesinlikle tatmin oldum) kullanılmıştır. İfadeler analiz neticesinde altı boyut (Turist ürünleri, havaalanı, ev sahibi tutumu, ulaşım, konaklama ve yiyecek-içecek, fiyat) altında toplanmıştır.

Vassiliadis (2008: 440), Kuzey Yunanistan'1 ziyaret eden Alman ve İngiliz turistlerin destinasyonda sunulan ürün ve hizmet algılarını, tekrar ziyaret niyetlerini ve tavsiye etme niyetlerini ölçmeyi amaçlamıştır. Bu bağlamda 4143 ziyaretçi ile yapılan çalışmada 24 ifadeye (1=çok kötü, 4= çok iyi) yer verilmiştir.

Asya ülkeleri olan Japonya, Kore ve Çin'den tatil amaciyla Yunanistan'a gelen turistlerin itici ve çekici motivasyonlarını belirlemek ve motivasyonlarına göre pazar bölümlendirmesi yapmak amacıyla Assiouras vd. (2015: 1404) çalışma gerçekleştirmişlerdir. Çalışmada, çekici faktörlerin belirlenmesi amacıyla 18 ifade $(1=$ tamamen katılmıyorum, 5= tamamen katılıyorum) kullanılmıştır. İfadeler dört boyut (dinlence, alışveriş ve güvenlik, çeşitlilik ve maliyet, kültür ve miras, seyahat ayarlamaları ve tesisler) altında gruplanmıştır.

Tablo 3' de Yunanistan'da yapılmış üç çalışmada yer verilen 67 ifade kendi içerisinde benzerlik gösterdiği düşünülen başlıklar altında toplanmış ve 20 özellik belirlenmiştir. Bunlar, doğa, yiyecek-içecek, tutum, hijyen ve temizlik, tarihi ve kültürel unsurlar, fiyat, konaklama, eğlence, altyapı, hizmet güvenlik, alışveriş, aktivite, bilgi vericilik, destekleyici unsurlar, aile odaklılık, havaalanı, çekicilikler, olumsuz unsurlar ve diğer olarak sınıflandırılmıştır. 
Tablo 2. İspanya ile İlgili Destinasyon Çekiciliklerinin Sınıflandırılması

\begin{tabular}{|c|c|c|c|c|c|}
\hline \multicolumn{2}{|c|}{ Havaalanı } & \multicolumn{2}{|c|}{ Konaklama } & \multicolumn{2}{|c|}{ Hijyen ve temizlik } \\
\hline $\begin{array}{l}\cdot \text { Havaalanında yaşanan } \\
\text { sorunlar } \\
\cdot \text { Havaalanında bulunan } \\
\text { olanaklar } \\
\cdot \text { Havaalanı ve destinasyon } \\
\text { arasındaki mesafe } \\
\cdot \text { Havaalanı ve destinasyon } \\
\text { arasında seyahatin rahatlığı } \\
\cdot \text { Havaalanında check in ve } \\
\text { check out hızı } \\
\cdot \text { Havaalanlarında İngilizce } \\
\text { işaretler bulunması }\end{array}$ & $\begin{array}{l}\text { Kozak ve } \\
\text { Rimmington, } \\
\text { 2000; Marin } \\
\text { ve Taberner, } \\
\text { 2008; }\end{array}$ & $\begin{array}{l}\cdot \text { Konaklama kalitesi } \\
\cdot \text { Konaklama kalitesi } \\
\cdot \text { Konaklama tesisleri } \\
\cdot \text { Konaklama kalitesi } \\
\cdot \text { Konaklama } \\
\cdot \text { Konaklamanın kalite standard } 1 \\
\cdot \text { Otelde hizmet düzeyi } \\
\cdot \text { Oteldeki ambiyans } \\
\cdot \text { Konaklama yerlerinde } \\
\text { İngilizce menü bulunması }\end{array}$ & $\begin{array}{l}\text { Alegre ve } \\
\text { Cladera, } \\
\text { 2009; Alegre } \\
\text { ve Cladera, } \\
\text { 2006; Kozak } \\
\text { vd., 2004; } \\
\text { Marin ve } \\
\text { Taberner, } \\
\text { 2008; Kozak } \\
\text { ve } \\
\text { Rimmington, } \\
2000\end{array}$ & $\begin{array}{l}\cdot \text { Temizlik } \\
\cdot \text { Halka açık alanların } \\
\text { temizliği } \\
\cdot \text { Temizlik } \\
\cdot \text { Sahil temizliği } \\
\cdot \text { Temizlik ve hijyen } \\
\cdot \text { Sahillerin temizliği } \\
\cdot \text { Genel hijyen ve } \\
\text { sanitasyon } \\
\cdot \text { Havaalanının } \\
\text { temizliği }\end{array}$ & $\begin{array}{l}\text { Alegre ve } \\
\text { Cladera, } \\
\text { 2009; Campo } \\
\text { ve Garau, } \\
\text { 2008; Alegre } \\
\text { ve Cladera, } \\
\text { 2006; Kozak } \\
\text { vd., 2004; } \\
\text { Marin ve } \\
\text { Taberner, } \\
2008 ; \text { Kozak } \\
\text { ve } \\
\text { Rimmington, } \\
2000\end{array}$ \\
\hline \multicolumn{2}{|l|}{ Eğlence } & \multicolumn{2}{|l|}{ Hizmet } & \multicolumn{2}{|c|}{ Güvenlik } \\
\hline $\begin{array}{l}\text { - Gece hayatı } \\
\text { - Dinlence aktiviteleri } \\
\text { - Gece hayatı } \\
\text { - Dinlence tesisleri } \\
\text { - Gece hayatı } \\
\text { - Gece hayatı ve eğlence } \\
\text { olanakları }\end{array}$ & $\begin{array}{l}\text { Alegre ve } \\
\text { Cladera, } \\
\text { 2009; Campo } \\
\text { ve Garau, } \\
\text { 2008; Alegre } \\
\text { ve Cladera, } \\
\text { 2006; Kozak } \\
\text { vd., 2004; } \\
\text { Marin ve } \\
\text { Taberner, } \\
\text { 2008; Kozak } \\
\text { ve } \\
\text { Rimmington, } \\
2000\end{array}$ & $\begin{array}{l}\text { - Otel dışındaki hizmetlerin } \\
\text { profesyonellikten uzak olması } \\
\text { · İngilizce yazılı materyallerin } \\
\text { varlığı } \\
\text { ·İngilizce broşürlerin varlığı } \\
\text { · Restoranlarda İngilizce menü } \\
\text { olması } \\
\text { · Müşteri şikâyetlerine cevap } \\
\text { verme } \\
\text { ·Diğer tatil beldelerine turların } \\
\text { varlığı }\end{array}$ & $\begin{array}{l}\text { Marin ve } \\
\text { Taberner, } \\
\text { 2008; Kozak } \\
\text { ve } \\
\text { Rimmington, } \\
2000\end{array}$ & $\begin{array}{l} \\
\\
\text { · Güvenlik } \\
\cdot \text { Güvenlik } \\
\cdot \text { - Kişisel güvenlik } \\
\cdot \text { Güvenlik } \\
\cdot \text { Genel olarak güvende } \\
\text { hissetme }\end{array}$ & $\begin{array}{l}\text { Alegre ve } \\
\text { Cladera, } \\
\text { 2009; Alegre } \\
\text { ve Cladera, } \\
\text { 2006; Kozak } \\
\text { vd., 2004; } \\
\text { Marin ve } \\
\text { Taberner, } \\
\text { 2008; Kozak } \\
\text { ve } \\
\text { Rimmington, } \\
2000\end{array}$ \\
\hline
\end{tabular}




\begin{tabular}{|c|c|c|c|c|c|}
\hline \multicolumn{2}{|c|}{ Altyapı } & \multicolumn{2}{|c|}{ Tutum } & \multicolumn{2}{|c|}{ İletişim } \\
\hline $\begin{array}{l}\cdot \text { Yolların durumu } \\
\cdot \text { İçilebilir su } \\
\cdot \text { Trafik akışı } \\
\cdot \text { Park etme olanakları } \\
\cdot \text { Erişsimi kolay } \\
\cdot \text { Aşırı trafik } \\
\cdot \text { Yolların durumu }\end{array}$ & $\begin{array}{l}\text { Kozak vd., } \\
2004 ; \text { Marin } \\
\text { ve Taberner, } \\
2008\end{array}$ & $\begin{array}{l}\cdot \text { Davranış } \\
\cdot \text { Misafirperverlik } \\
\cdot \text { Müşteri olarak davranış } \\
\cdot \text { Yerel halkın misafirperverliği } \\
\cdot \text { Davranış } \\
\cdot \text { Misafirperverlik } \\
\cdot \text { Turizmde çalışan personelin } \\
\text { tutumu }\end{array}$ & $\begin{array}{l}\text { Alegre ve } \\
\text { Cladera, } \\
\text { 2009; Campo } \\
\text { ve Garau, } \\
\text { 2008; Alegre } \\
\text { ve Cladera, } \\
\text { 2006; Kozak } \\
\text { ve } \\
\text { Rimmington, } \\
2000\end{array}$ & $\begin{array}{l}\text { - Diğer turistlerle } \\
\text { etkileşim } \\
\text { ·İngilizce konuşma } \\
\text { düzeyi }\end{array}$ & $\begin{array}{l}\text { Marin ve } \\
\text { Taberner, } \\
\text { 2008; Kozak } \\
\text { ve } \\
\text { Rimmington, } \\
2000\end{array}$ \\
\hline \multicolumn{2}{|c|}{ Tarihi ve kültürrel unsurlar } & \multicolumn{2}{|c|}{ Fiyat } & \multicolumn{2}{|c|}{ Bilgi vericilik } \\
\hline $\begin{array}{l}\cdot \text { Kültürel aktiviteler } \\
\cdot \text { Kültürel etkinlikler } \\
\cdot \text { Kültürel kaynaklar } \\
\cdot \text { Halk festivali } \\
\cdot \text { Tarihi alanlar ve yerler } \\
\cdot \text { Kültürel aktiviteler } \\
\cdot \text { Yerel yaşam biçimi } \\
\cdot \text { Müze ve tarihi yerlere gitme }\end{array}$ & $\begin{array}{l}\text { Alegre ve } \\
\text { Cladera, } \\
\text { 2009; Alegre } \\
\text { ve Cladera, } \\
\text { 2006; Kozak } \\
\text { vd., 2004; } \\
\text { Marin ve } \\
\text { Taberner, } \\
\text { 2008; Kozak } \\
\text { ve } \\
\text { Rimmington, } \\
2000\end{array}$ & $\begin{array}{l}\cdot \text { Yemeklerin fiyatı } \\
\cdot \text { Dinlence fiyatı } \\
\cdot \text { Alışveriş fiyatı } \\
\cdot \text { Yiyecek ve içecek fiyatı } \\
\cdot \text { Yemeklerin fiyatı } \\
\cdot \text { Dinlence fiyatı } \\
\cdot \text { Alışveriş fiyatı } \\
\cdot \text { Makul bütçe } \\
\cdot \text { Ucuz destinasyon } \\
\cdot \text { Pahalı } \\
\cdot \text { Paranın değeri }\end{array}$ & $\begin{array}{l}\text { Alegre ve } \\
\text { Cladera, } \\
\text { 2009; Campo } \\
\text { ve Garau, } \\
\text { 2008; Alegre } \\
\text { ve Cladera, } \\
\text { 2006; Marin } \\
\text { ve Taberner, } \\
\text { 2008; Kozak } \\
\text { ve } \\
\text { Rimmington, } \\
2000\end{array}$ & $\begin{array}{l}\cdot \text { Bilgi } \\
\cdot \text { İşaretlendirme } \\
\cdot \text { Bilgi verme } \\
\cdot \text { İşaretlendirme } \\
\cdot \text { Turist bilgilendirme } \\
\cdot \text { Bilgi alması kolay ve } \\
\text { ayarlamalar yapması } \\
\text { kolay } \\
\cdot \text { Yollarda ve ilgili } \\
\text { yerlerdeki } \\
\text { işaretlendirmeler }\end{array}$ & $\begin{array}{l}\text { Alegre ve } \\
\text { Cladera, } \\
\text { 2009; Alegre } \\
\text { ve Cladera, } \\
\text { 2006; Kozak } \\
\text { vd., 2004; } \\
\text { Marin ve } \\
\text { Taberner, } \\
\text { 2008; }\end{array}$ \\
\hline \multicolumn{2}{|l|}{ Aile odaklılık } & \multicolumn{2}{|c|}{ Destekleyici unsurlar } & \multicolumn{2}{|c|}{ Çekicilikler } \\
\hline $\begin{array}{l}\text { - Çocuk ve yetişkinler için } \\
\text { olanaklar } \\
\text { - Çocuklar için tesislerin } \\
\text { bulunması }\end{array}$ & $\begin{array}{l}\text { Kozak ve } \\
\text { Rimmington, } \\
2000 ; \text { Marin } \\
\text { ve Taberner, } \\
2008\end{array}$ & - Sahilde tesislerin bulunması & $\begin{array}{l}\text { Marin ve } \\
\text { Taberner, } \\
2008\end{array}$ & $\begin{array}{l}\text { - Çekiciliklerin } \\
\text { çeşitlilikleri } \\
\text { · Turizm çekicilikleri }\end{array}$ & $\begin{array}{l}\text { Kozak ve } \\
\text { Rimmington, } \\
\text { 2000; Marin } \\
\text { ve Taberner, } \\
2008\end{array}$ \\
\hline
\end{tabular}




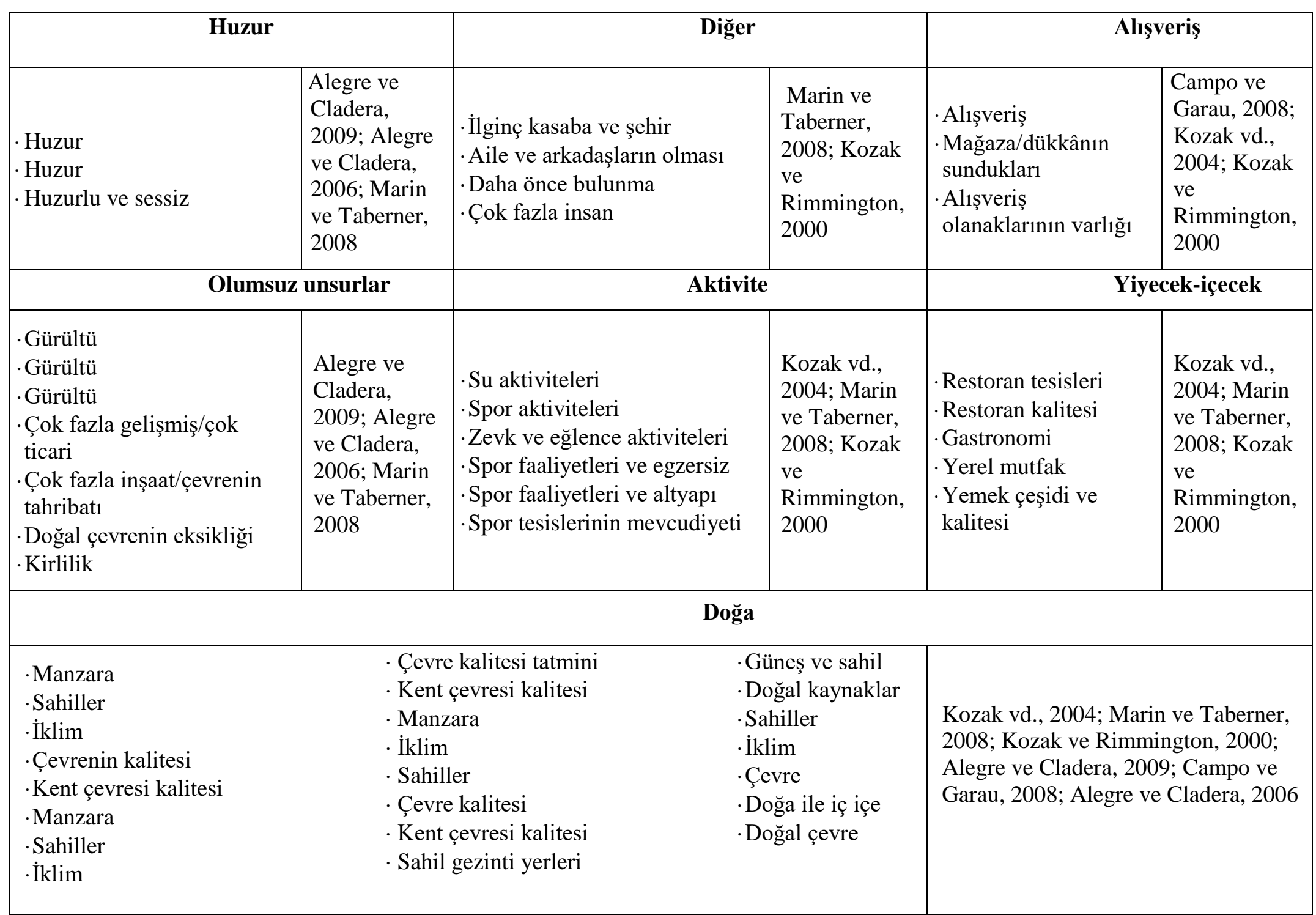


Tablo 3. Yunanistan ile İlgili Destinasyon Çekiciliklerinin Sınıflandırılması

\begin{tabular}{|c|c|c|c|c|c|}
\hline \multicolumn{2}{|c|}{ Tarihi ve kültürel unsurlar } & \multicolumn{2}{|c|}{ Hizmet } & \multicolumn{2}{|r|}{ Diğer } \\
\hline $\begin{array}{l}\cdot \text { Müze, sergi programları } \\
\cdot \text { Müze ve tarihi yerlerin } \\
\text { varlığı } \\
\cdot \text { Yunan sanat ve kültürü } \\
\cdot \text { Kültürel ve tarihi } \\
\text { alanlar/yerler } \\
\text { · Yunan tapınakları } \\
\cdot \text { Kültürel arz }\end{array}$ & $\begin{array}{l}\text { Vassiliadis, } \\
2008 ; \\
\text { Andriotis vd., } \\
2008 ; \\
\text { Assiouras vd. } \\
2015\end{array}$ & $\begin{array}{l}\text { · Müşteri şikayetlerine cevap } \\
\text { verebilme } \\
\text { · Taksi hizmetleri } \\
\text { · Günlük tur hizmetlerinin } \\
\text { varlığı } \\
\text { · Rehberli gezi ve turların } \\
\text { varlığı } \\
\text { · Tur firmaları tarafindan } \\
\text { sunulan tur programları }\end{array}$ & $\begin{array}{l}\text { Andriotis vd., } \\
2008 \\
\text { Assiouras vd. } \\
2015\end{array}$ & $\begin{array}{l}\text { ·Bölgenin imaj ve } \\
\text { güzelliği } \\
\text { · Kuzey Yunanistan'da } \\
\text { sunulan bütün turistik } \\
\text { ürünlerden } \\
\text { faydalanma } \\
\text {-Seyahat mesafesi ve } \\
\text { saat farkı } \\
\text {-Seyahat etmenin } \\
\text { uygunluğu ve tur } \\
\text { ayarlamanın kolaylığı }\end{array}$ & $\begin{array}{l}\text { Vassiliadis, } \\
2008 ; \\
\text { Assiouras vd. } \\
2015\end{array}$ \\
\hline \multicolumn{2}{|c|}{ Hijyen ve temizlik } & \multicolumn{2}{|c|}{ Konaklama } & \multicolumn{2}{|c|}{ Tutum } \\
\hline $\begin{array}{l}\text { - Düzenlilik/Çevre temizliği } \\
\cdot \text { Destinasyon havaalanın } \\
\text { temizliği } \\
\cdot \text { Konaklama temizliği } \\
\cdot \text { Hijyen ve temizlik düzeyi } \\
\cdot \text { Hijyen ve temizlik }\end{array}$ & $\begin{array}{l}\text { Vassiliadis, } \\
2008 ; \\
\text { Andriotis } \\
\text { vd., 2008; } \\
\text { Assiouras } \\
\text { vd. } 2015\end{array}$ & $\begin{array}{l}\cdot \text { Konaklanan yerin sessizliği } \\
\cdot \text { Konaklanan yerin tasarımı } \\
\cdot \text { Konaklanan yerin içinde ve } \\
\text { dışındaki hizmetler } \\
\cdot \text { Konaklamanın kalite standardı }\end{array}$ & $\begin{array}{l}\text { Vassiliadis, } \\
2008 \\
\text { Andriotis vd., } \\
2008\end{array}$ & $\begin{array}{l}\cdot \text { Misafirperverlik } \\
\cdot \text { Y Yerli halkın } \\
\text { sıcakkanlılığı } \\
\cdot \text { Dükkân sahibi ve } \\
\text { çalışanların tutumu } \\
\text { ·Şoförlerin tutumu } \\
\cdot \text { Yunanlıların } \\
\text { sicakkanlılığ1 }\end{array}$ & $\begin{array}{l}\text { Vassiliadis, } \\
2008 ; \\
\text { Andriotis } \\
\text { vd., 2008; } \\
\text { Assiouras } \\
\text { vd. } 2015\end{array}$ \\
\hline \multicolumn{2}{|c|}{ Havaalanı } & \multicolumn{2}{|c|}{ Destekleyici unsurlar } & \multicolumn{2}{|c|}{ Güvenlik } \\
\hline $\begin{array}{l}\text { Destinasyon havaalanında } \\
\text { bulunan olanaklar ve } \\
\text { hizmetlerin varlığ } 1 \\
\text { - Destinasyonda bulunan } \\
\text { havaalanında c/i ve c/o } \\
\text { hizmetinin hızı }\end{array}$ & $\begin{array}{l}\text { Andriotis vd., } \\
2008\end{array}$ & $\begin{array}{l}\cdot \text { Kongre merkezleri, kongre } \\
\text { alanları } \\
\cdot \text { Termal kaynaklar/terapi } \\
\cdot \text { Sağlık hizmetlerinin varlığı } \\
\cdot \text { Turistik yerlerin ve tesislerin } \\
\text { kalitesi }\end{array}$ & $\begin{array}{l}\text { Vassiliadis, } \\
2008 ; \\
\text { Andriotis vd., } \\
2008 ; \\
\text { Assiouras vd. } \\
2015\end{array}$ & $\begin{array}{l}\text { - Kişisel olarak } \\
\text { güvende ve emniyette } \\
\text { hissetme } \\
\text { · Güvenlik ve emniyet }\end{array}$ & $\begin{array}{l}\text { Andriotis vd., } \\
2008 ; \\
\text { Assiouras vd. } \\
2015\end{array}$ \\
\hline
\end{tabular}




\begin{tabular}{|c|c|c|c|c|c|}
\hline \multicolumn{2}{|c|}{ Bilgi vericilik } & \multicolumn{2}{|c|}{ Aktivite } & \multicolumn{2}{|c|}{ Altyapı } \\
\hline $\begin{array}{l}\text { Yerel seyahat acentesinden } \\
\text { veya bilgilendirme } \\
\text { bürolarından bilgi alma } \\
\text { - Bilgi bürosunun bulunması } \\
\text { - Seyahat ile ilgili bilgilerin } \\
\text { olması }\end{array}$ & $\begin{array}{l}\text { Vassiliadis, } \\
2008 ; \\
\text { Andriotis } \\
\text { vd., 2008; } \\
\text { Assiouras vd. } \\
2015\end{array}$ & $\begin{array}{l}\cdot \text { Spor ve hobi olanakları } \\
\cdot \text { Atletik tesislerin kalitesi } \\
\cdot \text { At binme, kuş gözlemleme, } \\
\text { bitki gözlemleme vb. } \\
\cdot \text { Spor tesislerinin ve } \\
\text { aktivitelerin varlığı } \\
\text { - Sahilde aktivitelerin varlığ }\end{array}$ & $\begin{array}{l}\text { Vassiliadis, } \\
\text { 2008; } \\
\text { Andriotis } \\
\text { vd., } 2008\end{array}$ & $\begin{array}{l}\text { · Ulaşım durumları } \\
\text { · Yürümek ve tur } \\
\text { atmak için caddeler } \\
\text { · Yerel ulaşım } \\
\text { hizmetlerinin konforu } \\
\text { · Yerel ulaşım ağı }\end{array}$ & $\begin{array}{l}\text { Vassiliadis, } \\
2008 ; \\
\text { Andriotis } \\
\text { vd., } 2008\end{array}$ \\
\hline \multicolumn{2}{|c|}{ Yiyecek-içecek } & \multicolumn{2}{|l|}{ Fiyat } & \multicolumn{2}{|r|}{ Doğa } \\
\hline $\begin{array}{l}\text { Konaklanan yerin içinde ve } \\
\text { dışında yemek kalitesi } \\
\cdot \text { Yemek kalitesi } \\
\cdot \text { Yunan yemeği }\end{array}$ & $\begin{array}{l}\text { Vassiliadis, } \\
2008 ; \\
\text { Andriotis } \\
\text { vd., 2008; } \\
\text { Assiouras vd. } \\
2015\end{array}$ & $\begin{array}{l}\text { ·Çekiciliklerin fiyat düzeyi } \\
\text { ·Hediyelik eşya fiyatları düzeyi } \\
\text { · Ürün ve hizmetlerin makul } \\
\text { fiyatı }\end{array}$ & $\begin{array}{l}\text { Andriotis vd., } \\
2008 \text {; } \\
\text { Assiouras vd. } \\
2015\end{array}$ & $\begin{array}{l}\cdot \text { Çevre ve manzara } \\
\cdot \text { İklim ve hava } \\
\cdot \text { Sahil kenarı/sahiller } \\
\cdot \text { Hava } \\
\cdot \text { Doğal manzara ve } \\
\text { çevre }\end{array}$ & $\begin{array}{l}\text { Vassiliadis, } \\
2008 \\
\text { Assiouras vd. } \\
2015\end{array}$ \\
\hline \multicolumn{2}{|c|}{ Alışveriş } & \multicolumn{2}{|c|}{ Aile odaklılık } & \multicolumn{2}{|c|}{ Çekicilikler } \\
\hline $\begin{array}{l}\text { - Mağazaların açık olma } \\
\text { saatleri } \\
\text { · Alışveriş yerlerinin } \\
\text { çeşitliliği }\end{array}$ & $\begin{array}{l}\text { Vassiliadis, } \\
\text { 2008; } \\
\text { Assiouras } \\
\text { vd. } 2015\end{array}$ & $\begin{array}{l}\text { · Konaklanılan yerde çocukları, } \\
\text { eğitmek, eğlendirmek, meşgul } \\
\text { etmek ve tutmak için özel } \\
\text { tesisler } \\
\text { ·Çocuklar için tesislerin varlığı }\end{array}$ & $\begin{array}{l}\text { Vassiliadis, } \\
2008 ; \\
\text { Andriotis vd., } \\
2008\end{array}$ & $\begin{array}{l}\text { - Turistik çekiciliklerin } \\
\text { çeşitliliği }\end{array}$ & $\begin{array}{l}\text { Assiouras vd. } \\
2015\end{array}$ \\
\hline \multicolumn{2}{|c|}{ Eğlence } & \multicolumn{2}{|c|}{ Olumsuz unsurlar } & & \\
\hline - Eğlence firsatları & $\begin{array}{c}\text { Vassiliadis, } \\
2008\end{array}$ & - Bankada sira bekleme & $\begin{array}{r}\text { Vassiliadis, } \\
2008\end{array}$ & & \\
\hline
\end{tabular}


Yukarda ele alınan araştırmalara baktığımızda, Türkiye ile ilgili incelenen on çalışmada ifadeler 23 özellik altında toplanmıştır. Bunlar eğlence, altyapı, güvenlik, alışveriş, konaklama, tarihi ve kültürel unsurlar, tutum, hizmet, fiyat, hijyen ve temizlik, yiyecek-içecek, doğa, aktivite, erişim, destekleyici unsurlar, bilgi vericilik, iletişim, olumsuz unsurlar, çekicilikler, huzur, havaalanı, aile odaklı ve diğerdir. Sınıflandırma sonucunda en fazla ifadenin yer aldığı özellik 24 ifade ile doğa olmuştur. Türkiye'nin üç tarafının denizlerle çevrili olması, geniş flora ve fauna alanı, elverişli iklimi, aynı anda birçok etkinliği yapmaya uygun havası gibi birçok özelliği araştırmacılar tarafından önemli görülmüş ve çalışmada sıklıkla yer verildiği görülmüştür. En fazla ifade ile temsil edilen ikinci özellik yiyecek-içecek (23) olmuştur. Bünyesinde farklı etnik gruptan birçok milleti barındıran, uygun iklim, coğrafyası ve toprak yapısı ile güzel bir harmoni oluşturan Türkiye'nin bu yapısı, zengin yemek kültürüne zemin hazırlamış olabilir. Bunların yanında, özellikle 2000'li yılların başından itibaren ve hızla uygulanmaya başlanan her şey dahil sistemi, turistlerin ayrı bir ücret ödemeden yiyecek ve içecekleri sınırsız bir şekilde tüketmelerinin önünü açmıştır. Bu gelişmeler yiyecek-içecek ile ilgili ifadelerin araştırmalarda sıklıkla yer almasına sebep olmuş olabilir. Ayrıca ziyaretçilerin, sunulan bu hizmetleri önemli bir çekicilik unsuru olarak gördükleri söylenebilir. Diğer en sık görülen özellik 20 ifade ile tutum olmuştur. Tutum kapsamında, halkın misafirperverliği, sıcakkanlılı̆̆ı, yardım etme isteği gibi ifadeler yer almaktadır. Türk halkının yabancılara karşı göstermiş olduğu içtenlik, samimiyet ve yardım etme isteğinin, önemli bir unsur olduğu ve ziyaretçilerin geldikleri destinasyonlarda iyi bir şekilde karşılanmalarının oldukça önemli olduğu söylenebilir. Bu durum, araştırmacılar tarafından dikkate alınmış ve önemli düzeyde araştırmalarında yer verdikleri görülmüştür. Diğer en sık görülen ifadelerin oluşturduğu özellikler ise sırasıyla hijyen ve temizlik (19), tarihi ve kültürel unsurlar (18), fiyat (17), konaklama (17), eğlence (14) ve altyapıdır (13).

İspanya ile ilgili özellikler incelendiğinde, ifadeler 22 özellik altında sınıflandırılmıştır. İspanya ile ilgili yapılan sınıflandırmalarda erişim ile ilgili bir ifadeye rastlanmadığ için grup oluşmamıştır. En sık yer alan ifade doğa (23) olmuştur. Bu sonuç, Türkiye ile benzer çıkmıştır. İspanya'da yer alan çalışmalar incelediğinde ağırlıklı olarak Balear Adaları'nda yürütüldüğü görülmektedir. Balear Adaları bünyesinde İbiza, Mayorka gibi dünyaca ünlü destinasyonları bulunduran bir adalar grubudur. Balear Adaları Avrupa'nın önemli bir deniz ve kum destinasyonudur (Alegre ve Cladera, 2006: 290). Bölgenin sahip olduğu doğal güzellikler ve iklim araştırmacılar tarafından oldukça önemli görülmüş ve toplamda en sık yer verilen çekicilik olmuştur. En sık ifade ile temsil edilen diğer bir özellik fiyat olmuştur. Bu grup altında, ürünlerin fiyat1, yiyecek- içecek fiyatı, pahalılık gibi ifadeler yer almıştır. İspanya'yı ziyaret eden turistler genellikle Avrupa ülkeleri vatandaşları olması ve özellikle Alman ve İngiliz (turizm güncel, 2019) gibi Avrupa'nın ekonomik olarak iyi durumda olan ülkelerinin vatandaşları olması fiyat konusunda hassasiyetlerini minimize edebilir. Bu bakımdan, bu ziyaretçilerin fiyat ile ilgili unsurlardan tatmin olmaları ve önemli görmeleri bekleneceğinden araştırmacılar tarafından sıklıkla yer verildiği söylenebilir. Sirasıyla diğer en sık görülen özellikler konaklama (9), hijyen ve temizlik (8), tarihi ve kültürel unsurlar (8), bilgi vericilik (7), altyapı (7), tutum (7) olmuştur.

Yunanistan'da yapılan çalışmalarda, ifadeler 20 özellik altında sınıflandırılmıştır. İfadelerin gruplandırılması neticesinde Yunanistan ile ilgili erişim, iletişim ve huzur özelikleri oluşmamıştır. En sık ifade ile temsil edilen özellik altı tane ile tarihi ve kültürel unsurlar olmuştur. Yunanistan, tarihi ve kültürel açıdan ele alındığında ülkenin ilk uygarlıklardan biri olduğu söylenebilir (aljazeera, 2019) ve Unesco Dünya Mirası Listesinde sahip olduğu 18 çekicilik (worldatlas, 2019) ile önemli bir Akdeniz ülkesi ve destinasyonudur. Bu bakımdan, ziyaretçilerin tarihi ve kültürel değerleri görmek için destinasyonu ziyaret etmeleri ve araştırmacıların bu durumu ortaya koymak amacıyla çalışmalar yapması kaçınılmazdır. Doğa, tutum, hijyen ve temizlik, hizmet ve aktivite ile ilgili beş ifadeye yer verilmiştir.

Elde edilen ifadelerden bir kısmı oluşturulan özellikler dışında kalmıştır. Bu ifadeler diğer özelliği altında ele alınmıştır. Gruplandırma sonucunda, İspanya ile ilgili erişim ifadelerine, Yunanistan ile ilgili erişim, iletişim ve huzur ifadelerine rastlanamamıştır. 
Tablo 4. Destinasyon Çekicilikleri/Özelikleri Sıklıklarının Ülkelere Göre Dağılımı

\begin{tabular}{|c|c|c|c|c|c|c|}
\hline & \multicolumn{2}{|c|}{ Türkiye } & \multicolumn{2}{|c|}{ İspanya } & \multicolumn{2}{|c|}{ Yunanistan } \\
\hline Çekicilikler/özellikler & $\begin{array}{c}\text { Çalışmalarda } \\
\text { yer alan } \\
\text { ifade sayısı }\end{array}$ & \begin{tabular}{|c|} 
Çalışma \\
başına \\
ifade \\
sayısı
\end{tabular} & $\begin{array}{c}\text { Çalışmalarda } \\
\text { yer alan } \\
\text { ifade sayısı }\end{array}$ & $\begin{array}{l}\text { Çalışma } \\
\text { başına } \\
\text { ifade } \\
\text { sayısı }\end{array}$ & $\begin{array}{l}\text { Çalışmalarda } \\
\text { yer alan } \\
\text { ifade sayısı }\end{array}$ & $\begin{array}{l}\text { Çalışma } \\
\text { başına } \\
\text { ifade } \\
\text { sayı1s1 }\end{array}$ \\
\hline Doğa & 24 & 2,4 & 23 & 3,8 & 5 & 1,7 \\
\hline Yiyecek-içecek & 23 & 2,3 & 5 & 0,8 & 3 & 1 \\
\hline Tutum & 20 & 2 & 7 & 1,2 & 5 & 1,7 \\
\hline Hijyen ve temizlik & 19 & $\overline{1,9}$ & 8 & 1,3 & 5 & 1,7 \\
\hline $\begin{array}{l}\text { Tarihi ve kültürel } \\
\text { unsurlar }\end{array}$ & 18 & 1,8 & 8 & 1,3 & 6 & 2 \\
\hline Fiyat & 17 & 1,7 & 11 & 1,8 & 3 & 1 \\
\hline Konaklama & 17 & $\overline{1,7}$ & 9 & $\overline{1,5}$ & 4 & $\overline{1,3}$ \\
\hline Eğlence & 14 & 1,4 & 6 & 1 & 1 & 0,3 \\
\hline Altyap1 & 13 & 1,3 & 7 & 1,2 & 4 & 1,3 \\
\hline Hizmet & 12 & 1,2 & 6 & 1 & 5 & $\overline{1,7}$ \\
\hline Güvenlik & 11 & $\overline{1,1}$ & 5 & 0,8 & 2 & 0,7 \\
\hline Alışveriş & 10 & 1 & 3 & 0,5 & 2 & 0,7 \\
\hline Aktivite & 9 & 0,9 & 6 & 1 & 5 & 1,7 \\
\hline Bilgi vericilik & 5 & 0,5 & 7 & 1,2 & 3 & 1 \\
\hline İletişim & 4 & $\overline{0,4}$ & 2 & 0,3 & - & - \\
\hline Destekleyici unsurlar & 4 & 0,4 & 1 & 0,2 & 4 & 1,3 \\
\hline Erişim & 4 & 0,4 & - & 0 & - & - \\
\hline Aile odakl1 & 3 & 0,3 & 2 & 0,3 & 2 & 0,7 \\
\hline Havaalanı & 2 & 0,2 & 6 & 1 & 2 & 0,7 \\
\hline Huzur & 1 & 0,1 & 3 & 0,5 & - & - \\
\hline Çekicilikler & 1 & 0,1 & 2 & 0,3 & 1 & 0,3 \\
\hline Olumsuz unsurlar & 1 & 0,1 & 6 & 1 & 1 & 0,3 \\
\hline $\begin{array}{l}\text { Diğer* (daha önce } \\
\text { bulunma, İranlilara } \\
\text { vize muafiyeti vs.) }\end{array}$ & 6 & 0,6 & 4 & 0,7 & 4 & 1,3 \\
\hline
\end{tabular}

* Çalışmalarda, bir özellik altına yerleştirilemeyen ifadeler diğer başlığı altında ele alınmıştır. 
Çalışma kapsamında ele alınan üç ülke ile ilgili farklı sayıda çalışmanın incelenmesi, özellikleri oluşturan ifadelerin sayılarında önemli farklılıkların oluşmasına yol açmışıır. Özellikler altında yer alan ifadelerin çalışma başına düşen oranlarını ortaya koymak amacıyla elde edilen ifade sayısı çalışma sayısına bölünmüştür. Böylece, ülkeler arasında ifadelerin ortalama sıklı̆̆ ortaya konabilmiştir. Doğa ile ilgili ifadeler, İspanya'da ele alınan çalışmalarda ortalama 3,8 defa yer alırken, Türkiye'de 2,4 ve Yunanistan'da 1,7 kez yer almıştır. Türkiye'de ki çalışmalarda yiyecek-içecek 2,3 ifade ortalaması ile, Yunanistan $(1)$ ve İspanya'ya $(0,8)$ göre daha fazla çıkmıştır. Bunun sebebi, daha önce de ifade edildiği üzere, her şey dahil sisteminin Türkiye'de başarılı bir şekilde ele alınması olabilir. Tutum ile ilgili ifadelerde Türkiye 2 ortalama ile diğer iki ülkeden fazla ortalamaya sahiptir. Özellikle son yıllarda, İspanya ve Yunanistan'da toplum tarafından turistlere karşı eylemler olduğu görülmektedir (BBC, 2019; NTV, 2019). Turizm ile oluşan kalabalık ve pahalılık halkın tepkisine neden olduğu söylenebilir. Diğer yandan çalışmalarda genellikle pozitif unsurlara yer verilmesinden dolayı, olumsuz sayılabilecek bu gibi ifadelerin, bu iki ülkede daha az yer verilmesine yol açtığı söylenebilir. Tarihi ve kültürel unsurlar ile ilgili ifadeler de ise Yunanistan'daki çalışmalarda ortalama 2 ifadeye yer verilirken, Türkiye'de 1,8 ve İspanya'da 1,3 ifadeye yer verilmiştir. Fiyat ile ilgili ifadeler ise çalışmalarda İspanya 1,8 , Türkiye 1,7 ve Yunanistan 1 ortalama ile temsil edilmiştir. Çalışmada, diğer başlığı altında toplanan ifadelerin ayrı birer grup olarak tanımlanması yerine tek bir çatı altında toplanmıştır.

\section{SONUÇ VE TARTIŞMA}

Destinasyon çekiciliklerini belirlemek ve pazarlama girişimlerini yapmak oldukça önemlidir. Çünkü, destinasyona gelecek ziyaretçiler destinasyon tercihlerini bu çekicilikleri dikkate alarak yapmaktadırlar (Tekin, 2012: 30).

$\mathrm{Bu}$ araştırmada, Türkiye, İspanya ve Yunanistan ile ilgili destinasyon çekiciliklerini ölçmek amacıyla gerçekleştirilmiş çalışmalarda yer verilen ifadeler incelenmiş ve sınıflandırılmıştır. Bu kapsamda, her bir ülke için yapılan çalışmalar ayrı ayrı incelenmiş ve destinasyon çekicilikleri ile ilgili ifadeler belirlenmiştir. İfadeler, kendi içerisinde, benzerlik durumuna göre yazar tarafından sınıflandırmaya tabi tutulmuştur. Sinıflandırmalar oluşturulurken literatürde yer alan boyutlar referans alınmıştır (örn. alışveriş ve aktiviteler (Güzel ve Güzel, 2017) ve fiyat (Alegre ve Cladera, 2009)). Daha sonra, elde edilen özellikler, ülkeler arasında karşılaştırılmış ve çalışma başına ortaya konan ilgili ifade sayısı belirlenmeye çalışılmıştır (Tablo 4). Böylece, çalışmaya katılanlar için ilgili ülke için hangi özelliğin daha sık ortaya çıktığı belirlenmeye çalışılmıştır.

Daha önce de ifade edildiği üzere, çalışmalarda genel olarak pozitif unsurlar üzerinde durulmuştur. Bazı çalışmalarda, gürültü, kirlilik ve çevre tahribatı gibi ziyaretçilerin memnuniyetsizliğine yol açabilecek unsurları temsil eden ifadelere de yer verildiği görülmüştür. Bu ifadeler Tablo 4' de olumsuz unsurlar grubu altında ele alınmıştır. Bu ifadeler, İspanya ile ilgili çalışmalarda diğer iki ülkeye göre daha sık yer verilmiştir. Marin ve Taberner (2008: 13) Mayorka'da yaptıkları çalışmada bu ifadeleri tatminsizlik unsurları (dissatisfaction elements) olarak ifade etmişlerdir.

Sonuç olarak, üç önemli destinasyonu konu alan çalışmalardan elde edilen ifadeler neticesinde, üç ülkenin de sahip olduğu çekicilikler büyük oranda benzerlik gösterdiği söylenebilir. Rekabet içerisinde olan bu ülkeler, büyük oranda $3 \mathrm{~S}$ motivasyonuyla seyahat eden turistleri çekmektedir. Bu bakımdan farlılık yaratıp, rakiplerinden ayrı olarak yeni çekicilikler oluşturmak önemlidir. Destinasyonlar, özellikle internet ve teknoloji uygulamalarının hayatımızın her alanında olduğu günümüzde, akıllı şehir uygulamaları ve mobil uygulamalar ile ziyaretçilerin tatil deneyimlerini şekillendirebilirler. Örneğin, Çinlilerin alışverişlerinde klasik yöntemle ödeme yerine mobil uygulamalar (WeChat ve Alipay) kullanmaları yaygınlaşmaktadır (travelchinacheaper.com). Bu bakımdan, Çinli turistlerin destinasyon tercihlerinde bu kriteri dikkate almaları beklenebilir. Diğer ziyaretçiler için de geliştirilebilecek yeni uygulamalar ile deneyimler zenginleştirilebilir. Dolayısıyla, ilerleyen dönemlerde teknoloji odaklı yeni destinasyon çekicilikleri, tüketicilerin destinasyon tercihleri üzerinde rol alabilir.

Her çalışmada olduğu gibi bu çalışmanın da bazı sınırlılıkları bulunmaktadır. İlk olarak, İngilizce ve Türkçe dillerinde yapılan çalışmalar dikkate alınmıştır. İspanyolca ve Yunanca ya da diğer dillerde yapılan çalışmaların kapsam dışında tutulması bu çalışmanın bir sınırlılığıdır. Ayrıca, Akdeniz havzasında Kuzey Afrika ülkeleri ile birlikte, Kuzey Kıbrıs, Güney Kıbrıs, Malta, İtalya, Hırvatistan ve Fransa gibi diğer önemli destinasyonlar da bulunmaktadır. Gelecek çalışmalarda, bu ülkeler de benzer bir çalışma kapsamında ele alınabilir. Diğer yandan, konu ile ilgili çalışmalardan tamamına ulaşılmaya çalışılsa da bazı araştırmalara ulaşılamamış olabilir. Sonraki çalışmalarda, daha fazla veri tabanı ve anahtar kelime ile farklı çalışmalara ulaşılabilir. Son olarak, yazar ifadeleri gruplandırma aşamasında büyük ölçüde literatürden faydalansa da öznel davranışlar da sergilemiştir. Bu sebeple, farklı araştırmacılara göre bazı ifadeler farklı özellikler altında gösterilebilir. 


\section{KAYNAKÇA}

Aksöz, E. Ozan, (2010). “Turizm Pazarlamasının Organizasyonunda Destinasyon Pazarlama Örgütleri ve Türkiye için Uygun Örgüt Yapısının Belirlenmesine Yönelik Bir Araştırma”. Doktora Tezi, Anadolu Üniversitesi, Sosyal Bilimler Enstitüsü, Eskişehir.

Aktaş, Ahmet, Çevirgen, Aydın ve Toker, Boran, (2010). "Tourists' Satisfaction and Behavioral Intentions on Destination Attributes: An Empirical Study in Alanya". Tourism Analysis, 15(2), s. 243-252.

Albayrak, Tahir ve Caber, Meltem, (2013). "The Symmetric and Asymmetric Influences of Destination Attributes on Overall Visitor Satisfaction". Current Issues in Tourism, 16(2), s. 149-166.

Alegre, Joaquín ve Cladera, Magdalena, (2006). "Repeat Visitation in Mature Sun and Sand Holiday Destinations". Journal of Travel Research, 44(3), s. 288-297.

Alegre, Joaquín ve Cladera, Magdalena, (2009). "Analysing the Effect of Satisfaction and Previous Visits on Tourist Intentions to Return". European Journal of Marketing, 43(5/6), s. 670-685.

Alhroot, A. H H. Jaddou, (2007). "Marketing of a Destination: Jordan as a Case Study". Doktora Tezi, Huddersfield Üniversitesi, Huddersfield.

Andriotis, Konstantinos, Agiomirgianakis, George ve Mihiotis, Athanasios (2008). "Measuring Tourist Satisfaction: A Factor-cluster Segmentation Approach". Journal of Vacation Marketing, 14(3), s. 221-235.

Assiouras, Ioannis, Skourtis, George, Koniordos, Michalis, ve Giannopoulos, A. Antoios, (2015). "Segmenting East Asian Tourists to Greece by Travel Motivation". Asia Pacific Journal of Tourism Research, 20(12), s. 1389-1410.

Bahar, Ozan ve Kozak, Metin, (2012). Turizm Ekonomisi. Detay Yayıncılık, Ankara.

Buhalis, Dimitrios, (2000). "Marketing the Competitive Destination of the Future". Tourism Management, 21(1), s.97116.

Caber, Meltem, Albayrak, Tahir ve Matzler, Kurt, (2012). "Classification of the Destination Attributes in the Content of Competitiveness (by revised importance-performance analysis)". Journal of Vacation Marketing, 18(1), s. 43-56.

Campo, Sara ve Garau, Joan, B, (2008). "The Influence of Nationality on the Generation of Tourist Satisfaction with a Destination". Tourism Analysis, 13(1), s. 81-92.

Chahal, Hardeep ve Devi, Asha, (2015). "Destination Attributes and Destination Image Relationship in Volatile Tourist Destination: Role of Perceived Risk". Metamorphosis, 14(2), s. 1-19.

Çelik, P, (2014). “Antalya Turizm Destinasyonunun Rekabetçilik Analizi”. Doktora Tezi. Akdeniz Üniversitesi, Sosyal Bilimler Enstitüsü, Antalya.

Çetinsöz, B. Cevdet ve Artuğer, Savaş, (2014). "Yabancı Turistlerin Antalya'yı Tercih Etmesinde Etkili Olan Çekici Faktörlerin Belirlenmesine Yönelik bir Araştırma”. Journal of International Social Research, 7(32), s. 573-582.

Falzon, Joseph, (2012). "The Price Competitive Position of Mediterranean Countries in Tourism: Evidence from the Thomson Brochure". Tourism Management, 33(5), s. 1080-1092.

Fayos-Solá, Eduardo, (1996). “Tourism Policy: A Midsummer Night's Dream? Tourism Management, 17(6), s. 405-412. Gee, Chuck, Y., Choy, Dexter, J., ve Makens, James C., (1984). The Travel Industry. AVI Publishing Company, Inc.

Göker, Gönül, (2018). “Açık Alanda Yapılan Doğa Temelli Rekreatif Etkinlikler ve Destinasyon Markalaşması (Ilgaz Dağı Milli Parkı Örneği)”. Doktora Tezi. Gazi Üniversitesi, Sosyal Bilimler Enstitüsü, Ankara.

Güzel, Berrin, (2017). "Destination Attributes in the Eye of the Local People”. Kastamonu Üniversitesi İktisadi ve İdari Bilimler Fakültesi Dergisi, 18(1), s. 128-137.

Güzel, Özlem ve Güzel, Berrin, (2017). "The Influence of Films on Destination Attributes (DAs) for Arabian Tourists in Turkey”. International Journal of Business and Information, 12(3), s. 209-242.

Haarhoff, Rene ve Gany, Kulsum, B., (2017). “Attributes that Influence Resort Attractiveness: A Case Study of Selected Kimberley Resorts". African Journal of Hospitality, Tourism and Leisure, 6(3), s. 1-21.

https://www.aljazeera.com.tr/ulke-profili/ulke-profili-yunanistan, son erişim tarihi: 21.01.2019

https://www.bbc.com/turkce/haberler-dunya-40839361, son erişim tarihi: 21.01.2019

https://www.ntv.com.tr/dunya/yunanistanin-santorini-adasi-artik-turist istemiyorr8ngOOAOfEONKOV301xHxw, son erişim tarihi: 21.01.2019

https://www.travelchinacheaper.com/using-wechat-alipay-china-expat-guide, son erişim tarihi: 18.01.19

https://www.turizmguncel.com/haber/ispanya-sadece-bu-4-ulkeden-28-milyon-turist-aldi-7-ayda-50-milyonu-devirdih32717.html, son erişim tarihi: 18.01 .19

https://www.worldatlas.com/articles/countries-with-the-most-unesco-world-heritage-sites.html, son erişim tarihi: 21.01.2019

Kim, J. Hyeong, (2014). “The Antecedents of Memorable Tourism Experiences: The Development of a Scale to Measure the Destination Attributes Associated with Memorable Experiences". Tourism Management, 44, s. 34-45.

Klenosky, David, B. (2002). "The "Pull” of Tourism Destinations: A Means-end Investigation". Journal of Travel Research, 40(4), s. 396-403.

Kozak, Metin ve Rimmington, Mike, (2000). "Tourist Satisfaction with Mallorca, Spain, as an Off-Season Holiday Destination". Journal of Travel Research, 38(3), s. 260-269.

Kozak, Metin, (2002). "Destination Benchmarking". Annals of Tourism Research, 29(2), s. 497-519.

Kozak, Metin, Bigné, Enrique, ve Andreu, Luisa, (2005). "Satisfaction and Destination Loyalty: A Comparison between Non-repeat and Repeat Tourists". Journal of Quality Assurance in Hospitality and Tourism, 5(1), s. 43-59.

MacCannell, Dean, (1976). The Tourist: A New Theory of the Leisure Class. London: Macmillan. 
Mahdzar, Mazlina, Shuib, Ahmad, Ramachandran, Sridar ve Mohammad Afandi, Syamsul, Herman, (2015). "The Role of Destination Attributes and Memorable Tourism Experience in Understanding Tourist Revisit intentions". Tourism ve Environment, Social and Management Sciences, 15, s. 32-39.

Marin, Joaquín, Alegre ve Taberner, Jaume Garau, (2008). "Satisfaction and Dissatisfaction with Destination Attributes: Influence on Overall Satisfaction and the Intention to Return”. http://www.esade.edu/cedit/pdfs/papers/pdf6.pdf, son erişim tarihi: 13.01.2019.

Mehmetoglu, Mehmet ve Normann, Øystein, (2013). "What Influences Tourists' Overall Holiday Experience? Tourism Company Products versus Destination Products". European Journal of Tourism Research, 6(2), s. 183-191.

Nikjoo, Adel, H. ve Ketabi, Mahmoud, (2015). "The role of Push and Pull Factors in the Way Tourists Choose Their Destination". Anatolia, 26(4), s. 588-597.

Ozdemir, Bahattin, Aksu, Akın, Ehtiyar, Rüya, Çizel, Beykan ve Çizel, R. B., ve İçigen, Ebru Tercan, (2012).” Relationships among Tourist Profile, Satisfaction and Destination Loyalty: Examining Empirical Evidences in Antalya Region of Turkey". Journal of Hospitality Marketing ve Management, 21(5), s. 506-540.

Öter, Zafer ve Özdoğan, Osman, N, (2005). "Kültür Amaçlı Seyahat Eden Turistlerde Destinasyon İmajı: Selçuk-Efes Örneği”". Anatolia: Turizm Araştırmaları Dergisi, 16(2), s. 127-138.

Patsouratis, Vasilios, Frangouli, Zoe ve Anastasopoulos, George, (2005). "Competition in tourism among the Mediterranean countries". Applied Economics, 37(16), s. 1865-1870.

Pektaş, Fatih, (2017). "Seyahat Motivasyonunu Oluşturan İtici ve Çekici Faktörlerin Tüketici Temelli Destinasyon Değeri Üzerine Etkisi”. Doktora Tezi. Nevşehir Hacı Bektaş Veli Üniversitesi, Sosyal Bilimler Enstitüsü, Nevşehir.

Rajaratnam, Sushila, Devi, Nair, Vikneswaran, Pahlevan Sharif, Saeed ve Munikrishnan, Uma, Thevi, (2015). "Destination Quality and Tourists' Behavioural Intentions: Rural Tourist Destinations in Malaysia". Worldwide Hospitality and Tourism Themes, 7(5), s. 463-472.

Tekin, N.A. (2012). "Turistik Destinasyon Pazarlaması ve Çeşme Örneği”. Doktora Tezi. Ege Üniversitesi, Sosyal Bilimler Enstitüsü, İzmir.

Tosun, Cevat ve Jenkins, Carson, L., (1996). "Regional Planning Approaches to Tourism Development: The Case of Turkey". Tourism Management, 17(7), s. 519-531.

Truong, Thi, Lan, Huong, Lenglet, François ve Mothe, Caroline, (2018). "Destination Distinctiveness: Concept, Measurement, and Impact on Tourist Satisfaction". Journal of Destination Marketing ve Management, 8, s. 214231.

Vassiliadis, Chris, A., (2008). "Destination Product Characteristics as Useful Predictors for Repeat Visiting and Recommendation Segmentation Variables in Tourism: A CHAID Exhaustive Analysis". International Journal of Tourism Research, 10(5), s. 439-452.

Xu, Jing, Bill, (2010). "Perceptions of Tourism Products". Tourism Management, 31(5), s. 607-610.

Yuksel, Atila, (2001). "Managing Customer Satisfaction and Retention: A Case of Tourist Destinations, Turkey". Journal of Vacation Marketing, 7(2), s. 153-168. 